\title{
Scandinavian Oncophorus (Bryopsida, Oncophoraceae): species, cryptic species, and intraspecific variation
}

\author{
Lars HEDENÄS \\ Swedish Museum of Natural History, Department of Botany, \\ Box 50007, SE-104 05 Stockholm, Sweden. \\ E-mail: lars.hedenas@nrm.se
}

\begin{abstract}
Scandinavian members of the acrocarpous moss genus Oncophorus were revised after field observations had suggested unrecognized diversity. Based on molecular (nuclear: internal transcribed spacers 1 and 2, ITS; plastid: $\operatorname{trn} \mathrm{G}_{\mathrm{UCC}} \mathrm{G} 2$ intron, $\operatorname{trn} \mathrm{G}, r p s 4$ gene + trnS-rps 4 spacer, rps4) and morphological evidence, four morphologically distinguishable species are recognized, Oncophorus elongatus (I.Hagen) Hedenäs, O. integerrimus Hedenäs sp. nov. (syn. O. virens var. elongatus Limpr.), $O$. virens (Hedw.) Brid., and $O$. wahlenbergii Brid. (O. sardous Herzog, syn. nov.). Oncophorus elongatus was earlier recognized, but much of its variation was hidden within $O$. wahlenbergii. Its circumscription is here expanded to include plants with long leaves having mostly denticulate or sharply denticulate upper margins and with long and narrow marginal cells in the basal portion of the sheathing leaf lamina. The new species $O$. integerrimus sp. nov. differs from $O$. virens in having more loosely incurved leaves and entire or almost entire upper leaf margins. Besides these characters, the species in the respective pairs differ in quantitative features of the leaf lamina cells. Several cryptic entities were found, in several cases as molecularly distinct as some of the morphologically recognizable species, and phylogeographic structure is present within $O$. elongatus and $O$. virens.
\end{abstract}

Keywords. Geographic differentiation, habitat differences, morphology, Oncophorus integerrimus Hedenäs sp. nov., Principal Component Analysis.

Hedenäs L. 2017. Scandinavian Oncophorus (Bryopsida, Oncophoraceae): species, cryptic species, and intraspecific variation. European Journal of Taxonomy 315: 1-34. https://doi.org/10.5852/ejt.2017.315

\section{Introduction}

A significant proportion of species diversity is either not yet recognized, such as undescribed species, or hidden within morphologically closely similar or virtually identical species (Hawksworth 2001; Bickford et al. 2006; Crawford \& Stuessy 2016). During the last years this has been shown repeatedly for different bryophyte genera (Heinrichs et al. 2010; Carter 2012a, 2012b; Buchbender et al. 2014; Hedenäs et al. 2014; Draper et al. 2015). Oncophorus Brid. (von Bridel 1826) is another example of a moss genus for which species' circumscriptions are still unclear, and where it has not yet been tested if the many existing names at levels below the species reflect high intraspecific variation (e.g., Limpricht 1886; Mönkemeyer 1927; Nyholm 1987). Oncophorus (Dicranales: Oncophoraceae; Goffinet et al. 2008; Stech \& Frey 2008; Frey \& Stech 2009) includes acrocarpous species with leaves having a sheathing basal portion and a mostly long, gradually tapering, and narrowly triangular to almost linear 
upper portion. Species of Oncophorus are frequent in many wet or humid habitats in arctic to temperate regions of the Northern Hemisphere, and in addition some species occur in Sri Lanka or temperate areas of the Southern Hemisphere (Frahm et al. 1998; Frey \& Stech 2009).

In a relatively recent global treatment of Oncophorus, Frahm et al. (1998) recognized six species, down from twelve before their revision. Since then additional species were distinguished or described (Hedenäs 2005; Hedderson \& Blockeel 2006), and Frey \& Stech (2009) recognized nine species in the genus. Two of the species that Frahm et al. (1998) recognized, O. virens (Hedw.) Brid. (von Bridel 1826) and $O$. wahlenbergii Brid. (von Bridel 1826) are widespread and frequent in many areas of northern and central Scandinavia, but are rare in the south of Scandinavia (e.g., Hallingbäck et al. 2006). Some of the Scandinavian material considered by Frahm et al. (1998) as belonging to $O$. wahlenbergii has later been recognized as a species of its own, O. elongatus (I.Hagen) Hedenäs, restricted mainly to the mountains and the far north (Hedenäs 2005). Hagen (1899) originally distinguished this taxon by its large, yellowgreen, incoherent tufts, leaves $5.3 \mathrm{~mm}$ long and $1 \mathrm{~mm}$ wide, and a long-excurrent leaf costa.

Significant additional variation was observed during fieldwork in Norway and Sweden. Much of the variation could be interpreted as habitat-induced, but some was not possible to explain by this alone. For example, strikingly large plants forming lax tufts and with morphological affinities to $O$. wahlenbergii or O. elongatus occur along rocky shores of the Bothnian Sea and Bothnian Bay in Sweden, and O. virens s. lat. varies from tiny phenotypes in late snow-beds to large and lax phenotypes in fens. Finally, two specimens of $O$. virens $\mathrm{s}$. lat. with very different appearances were found growing close to each other in the same habitat on Mt. Åreskutan in Jämtland (C. Sweden), suggesting that some of the morphological variation was likely to have a genetic basis.

Information from morphology alone is evidently insufficient to interpret the variation within Scandinavian Oncophorus, or the taxonomy would already be clear and agreed on. Here, an approach including a wide molecular sampling of the Scandinavian taxa is combined with detailed morphological studies to explore (1) the circumscriptions of the so-far accepted taxa, and (2) whether additional species occur in the area. Based on the gathered information the circumscriptions of $O$. elongatus and $O$. wahlenbergii are considerably emended and $O$. virens s. lat. is divided into two species. In addition, several cryptic entities were detected and are discussed.

\section{Material and methods}

\section{Study species and material}

For the molecular evaluation, 24 Scandinavian specimens of $O$. elongatus, 22 of $O$. wahlenbergii, and 48 of $O$. virens s. lat. were studied. The species were sampled to represent different areas and environments in Scandinavia, as well as to cover the known morphological variation. Two specimens of the recently described species Oncophorus dendrophilus Hedd. \& Blockeel (Hedderson \& Blockeel 2006), from Cyprus and Crete, and two specimens of each of two other members of the genus, O. crispifolius (Mitt.) Lindb. (Lindberg 1872) and O. rauei (Austin) Grout (Grout 1937), were included for an assessment of the positions of $O$. virens and $O$. wahlenbergii within the genus. Based on Stech et al. (2012) two specimens of each of the two species Cynodontium strumiferum (Hedw.) Lindb. (Lindberg 1864) and Rhabdoweisia fugax (Hedw.) Bruch \& Schimp. (Bruch \& Schimper 1846), which appear in the clade sister to Oncophorus, were used as outgroup. The molecularly studied specimens are listed in Table 1.

The morphological analysis was based on specimens of $O$. elongatus-O. wahlenbergii and $O$. virens s. lat. that were included in the molecular analysis, whereas the geographical distribution of the species that were recognized for Scandinavia was mapped based on all Scandinavian material present in the Swedish Museum of Natural History (S). All Scandinavian S specimens were checked for their identity 


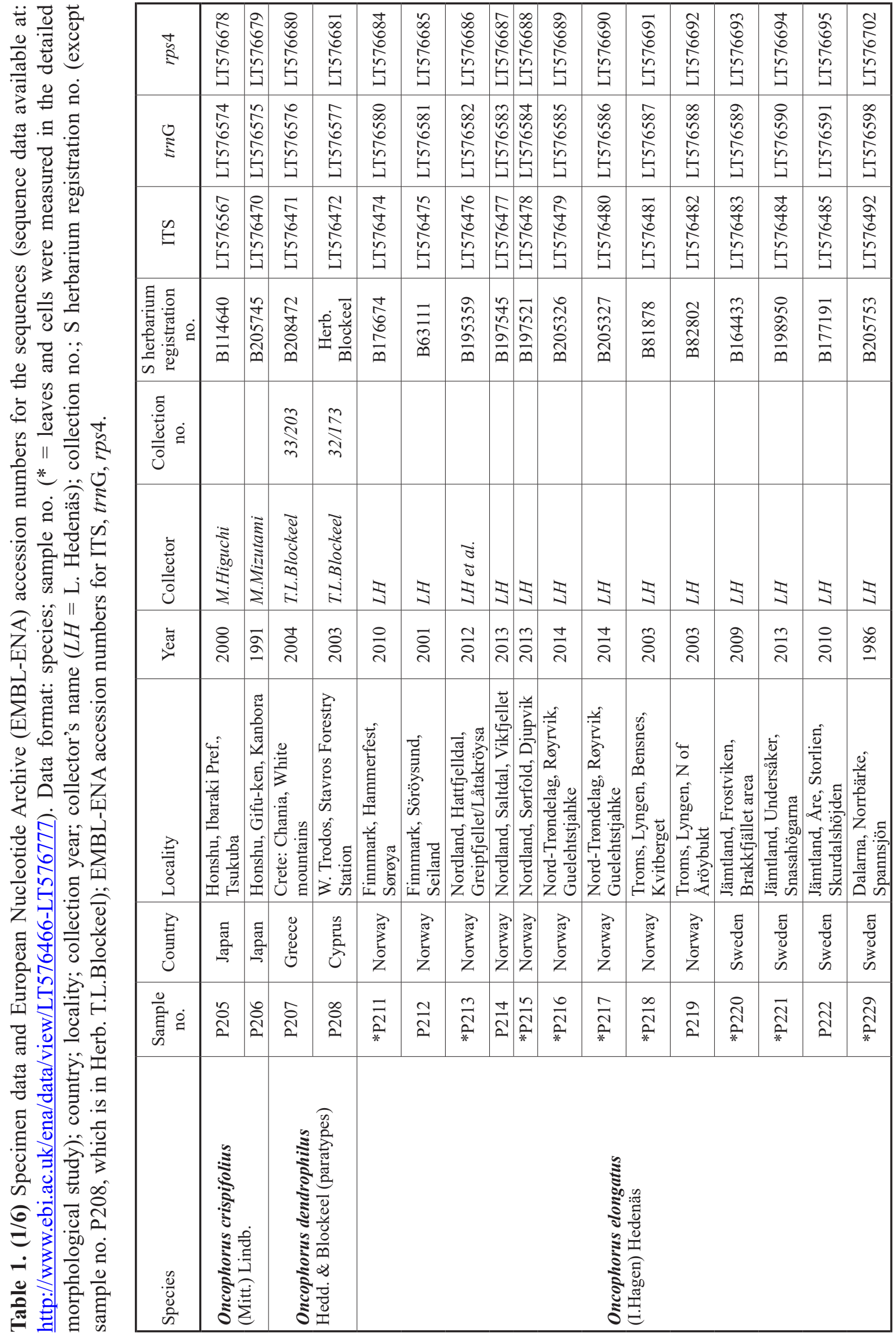




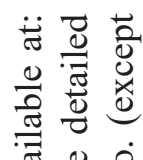

言导

䒕 $\Xi$.

8.

过

总老声

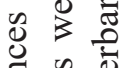

를

엉 n

क छ

Ð 25

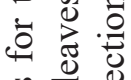

㐫

\begin{tabular}{|c|c|c|c|c|c|c|c|c|c|c|c|c|c|c|c|c|}
\hline 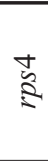 & 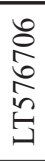 & 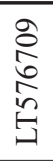 & 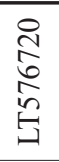 & 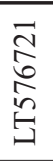 & 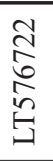 & 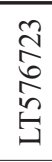 & 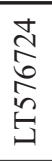 & 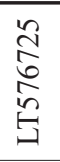 & 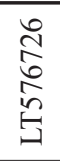 & 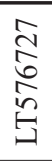 & 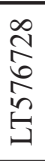 & $\begin{array}{l}0 \\
\stackrel{n}{n} \\
\stackrel{0}{0} \\
\hat{n} \\
\qquad\end{array}$ & 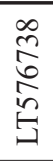 & $\begin{array}{l}\hat{n} \\
\hat{\sigma} \\
\hat{n} \\
ت \\
=\end{array}$ & & 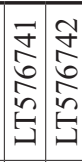 \\
\hline ह & 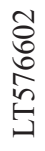 & $\begin{array}{l}2 \\
8 \\
8 \\
n \\
\hat{n} \\
=\end{array}$ & 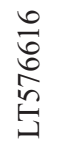 & 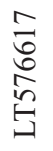 & 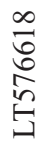 & $\begin{array}{l}\stackrel{a}{0} \\
\stackrel{0}{0} \\
i n \\
\ddots\end{array}$ & 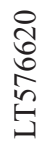 & $\begin{array}{l}\overrightarrow{\widehat{d}} \\
\stackrel{0}{0} \\
\hat{n} \\
\ddots\end{array}$ & 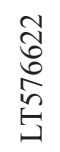 & 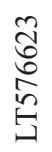 & 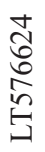 & 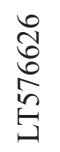 & 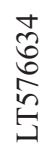 & $\begin{array}{l}n \\
\hat{\delta} \\
\delta \\
n \\
\omega\end{array}$ & & 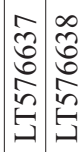 \\
\hline$\underline{E}$ & 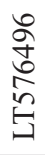 & 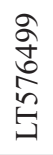 & $\begin{array}{l}0 \\
\sqrt[n]{ } \\
\hat{n} \\
\ddots \\
\end{array}$ & 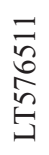 & 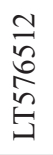 & 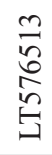 & $\begin{array}{l}\nabla \\
\frac{n}{6} \\
\sqrt[n]{n} \\
⿶\end{array}$ & $\begin{array}{l}n \\
\tilde{n} \\
\hat{n} \\
\hat{n}\end{array}$ & 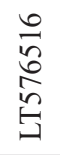 & $\begin{array}{l}\frac{1}{n} \\
6 \\
n \\
\hat{n}\end{array}$ & $\begin{array}{l}\infty \\
\vec{n} \\
\underline{\delta} \\
\omega \\
\omega\end{array}$ & 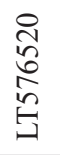 & $\begin{array}{l}\infty \\
\hat{n} \\
\sigma \\
\hat{n} \\
\hat{⿶}\end{array}$ & 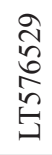 & 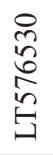 & 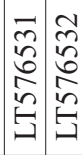 \\
\hline
\end{tabular}

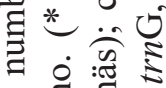

월

产造

ठ छ

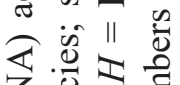

项造寻

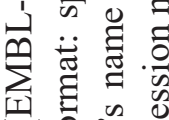

पै 效营造范

$<\dot{0}$

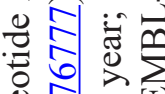

응 존ㄷ

خ

픈ㅎํㅇ

응 에

입 令

궁

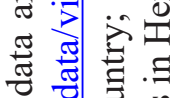

ฮ శ్రి

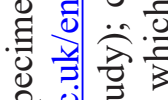

की

일

(2)

- -3

을

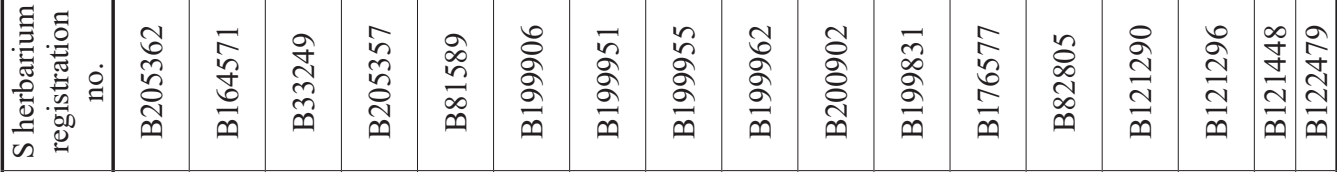

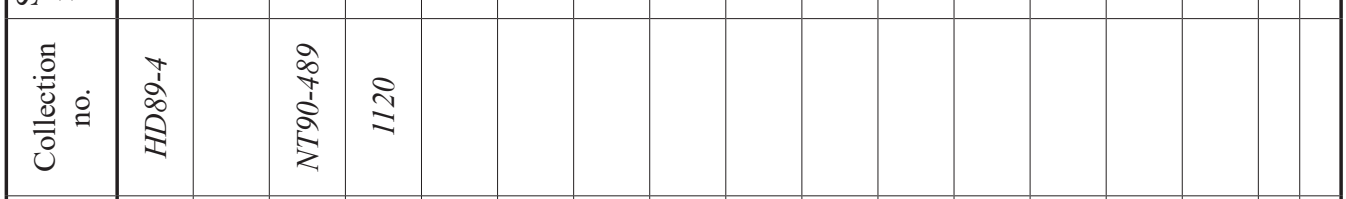

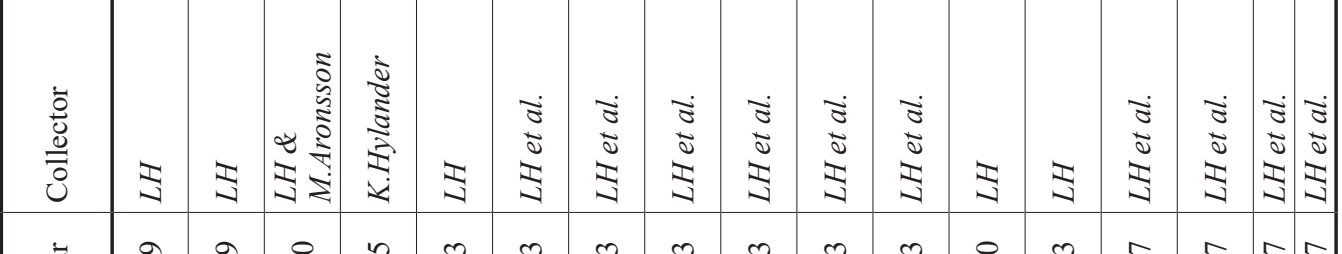

䒕

\begin{tabular}{|c|c|c|c|c|c|c|c|c|c|c|c|c|c|c|c|c|}
\hline 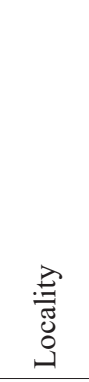 & 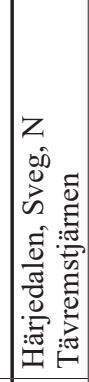 & 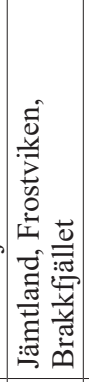 & 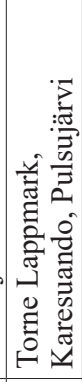 & 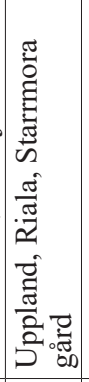 & 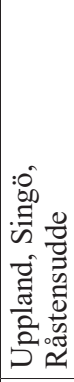 & 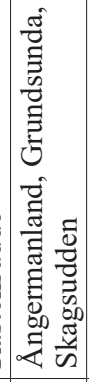 & 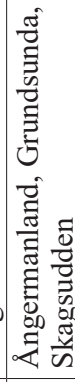 & 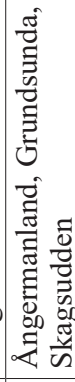 & 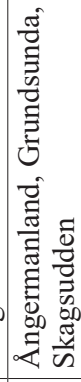 & 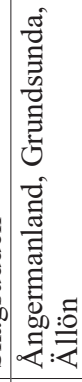 & 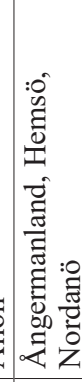 & 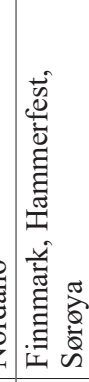 & 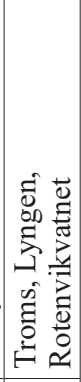 & 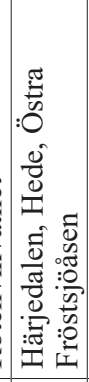 & 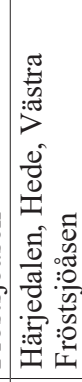 & 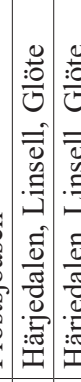 \\
\hline $\begin{array}{l}\text { 音 } \\
\text { 己े }\end{array}$ & 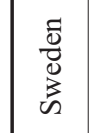 & 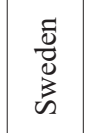 & 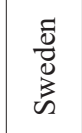 & 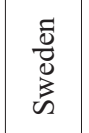 & 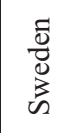 & 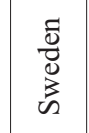 & 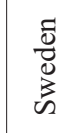 & 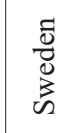 & 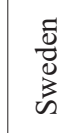 & 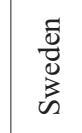 & 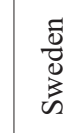 & $\begin{array}{l}\overrightarrow{\mathrm{d}} \\
\stackrel{0}{0} \\
\overrightarrow{\mathrm{z}}\end{array}$ & \begin{tabular}{l}
$\vec{d}$ \\
\multirow{2}{0}{} \\
$z$ \\
$z$
\end{tabular} & $\begin{array}{l}\overline{\tilde{J}} \\
\overline{0} \\
\dot{\Xi} \\
\bar{n}\end{array}$ & 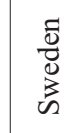 & 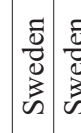 \\
\hline 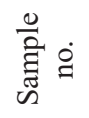 & $\underset{\widetilde{్}}{\widetilde{\hbar}}$ & 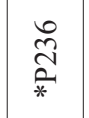 & 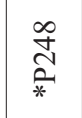 & $\underset{\text { Jे }}{\stackrel{a}{\widetilde{Z}}}$ & 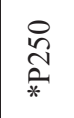 & $\stackrel{\bar{\beth}}{\check{\Sigma}}$ & 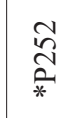 & & 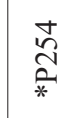 & 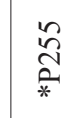 & 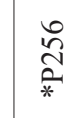 & 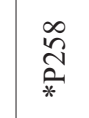 & 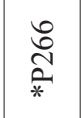 & 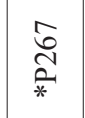 & 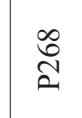 & \\
\hline
\end{tabular}




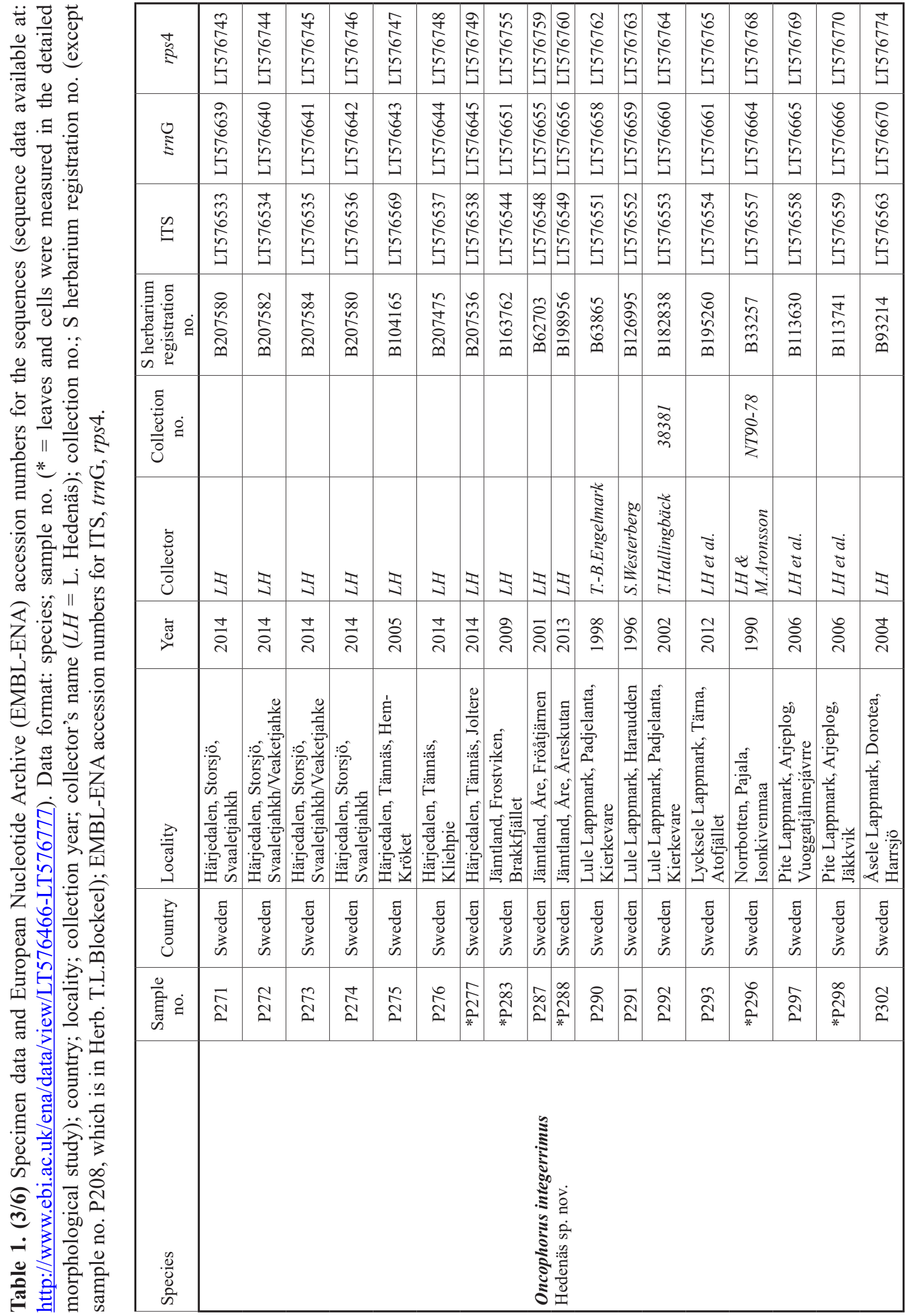




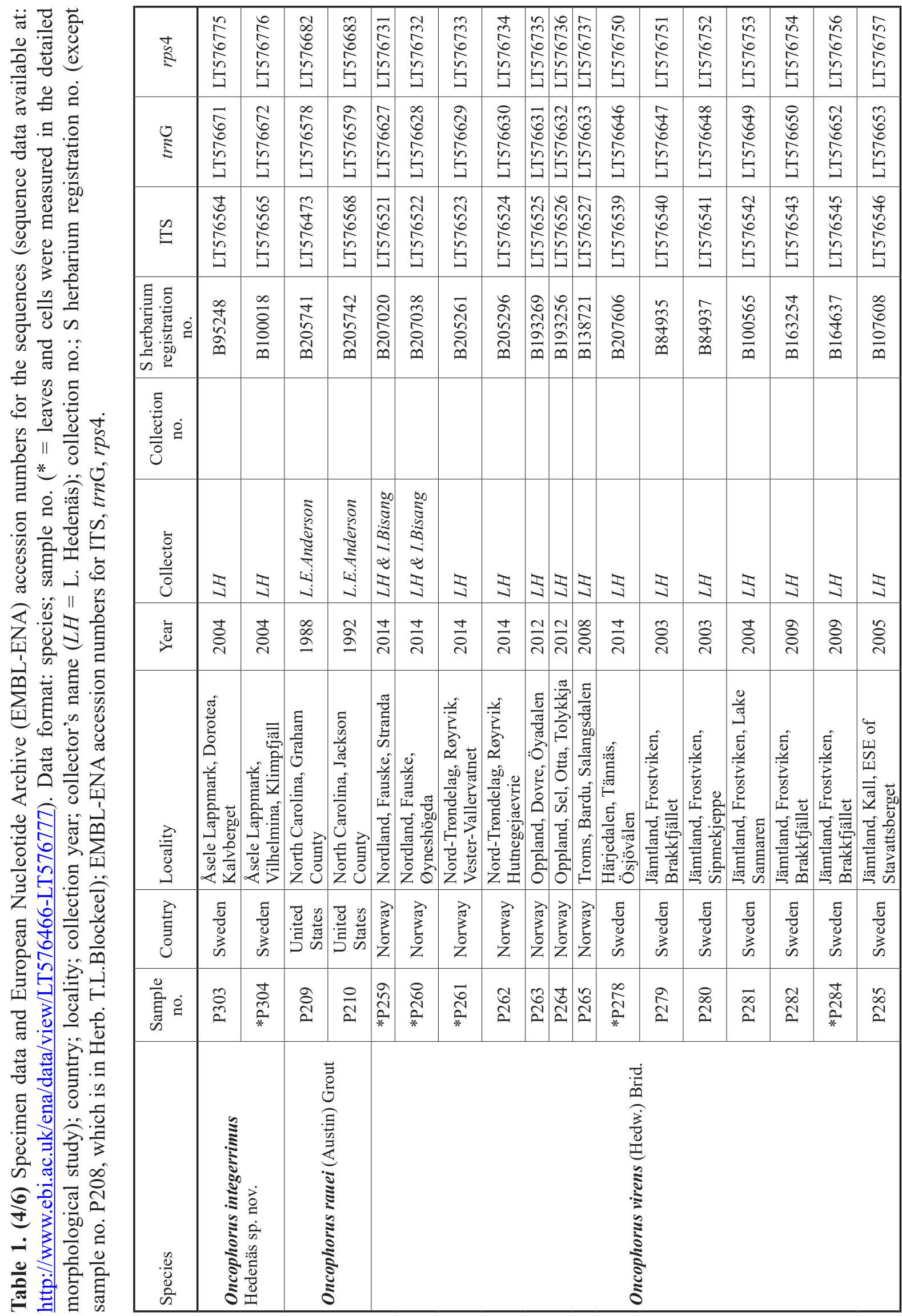




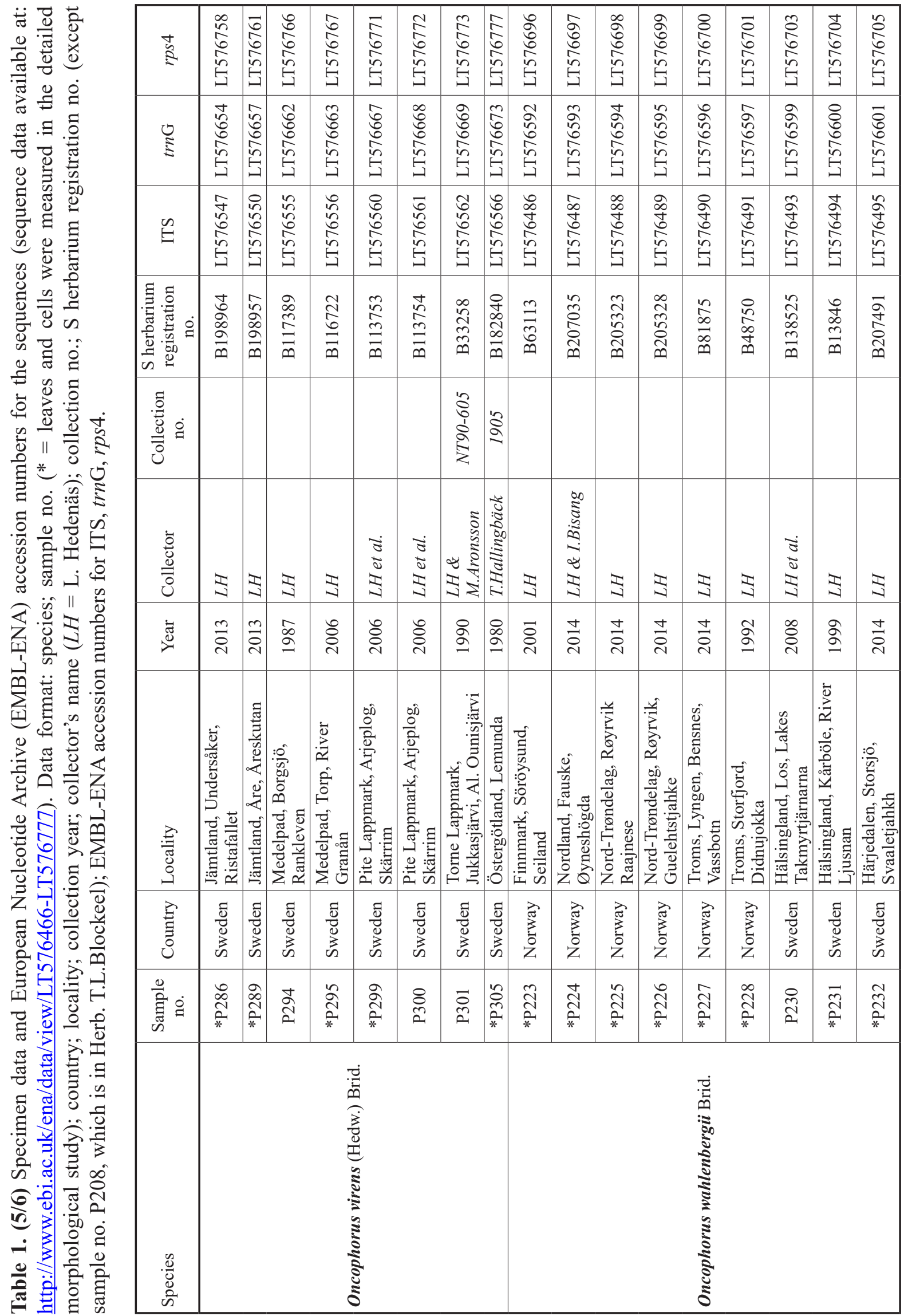




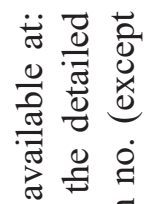

䒕 $\cong$.

8.5

ब

总

oิ 3

的

हैं 的

के

\&

t)

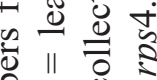

茟艺芒

实: 苛

을

过

论

«.

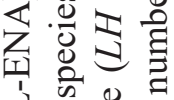

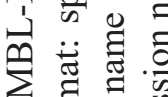

出

$\checkmark$ 훙

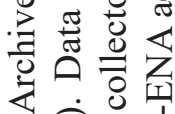

氞泀离

눌

㐘

ี ㄴํㅇㅎㅠ

¿ 0 ठ

을 空

氜氙号

플 웡

폴

要 专

ฮี

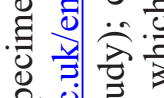

की

을 चี

-

- $\rightarrow \frac{0}{\circ}$

을

\begin{tabular}{|c|c|c|c|c|c|c|c|c|c|c|c|c|c|}
\hline 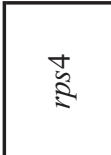 & $\begin{array}{l}\hat{\imath} \\
0 \\
\hat{0} \\
\hat{n} \\
G\end{array}$ & 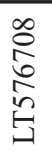 & 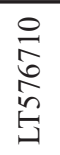 & 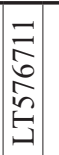 & 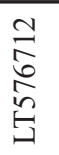 & 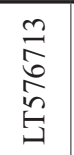 & 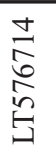 & 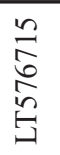 & 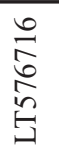 & \begin{tabular}{l}
$\stackrel{n}{7}$ \\
\multirow{0}{0}{} \\
$\hat{n}$ \\
$G$
\end{tabular} & 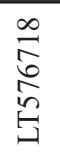 & 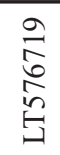 & 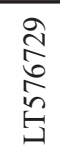 \\
\hline & 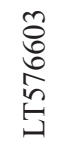 & 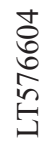 & 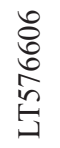 & 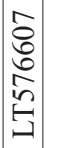 & $\begin{array}{l}\infty \\
0 \\
0 \\
0 \\
i n \\
\omega\end{array}$ & 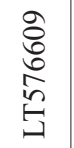 & 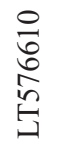 & 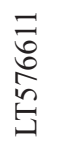 & 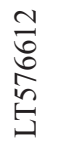 & $\begin{array}{l}m \\
\frac{m}{0} \\
\stackrel{0}{n} \\
\Xi\end{array}$ & 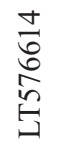 & 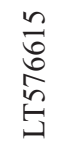 & 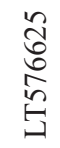 \\
\hline & \begin{tabular}{l}
$\hat{a}$ \\
\multirow{a}{0}{} \\
$\hat{n}$ \\
$\underline{y}$
\end{tabular} & 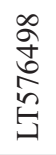 & 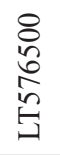 & 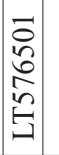 & 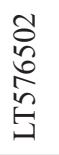 & $\begin{array}{l}n \\
0 \\
0 \\
n \\
i n \\
=\end{array}$ & 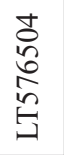 & 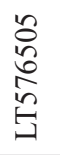 & 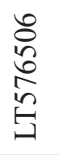 & $\begin{array}{l}\hat{n} \\
\hat{n} \\
\hat{n} \\
\underline{y}\end{array}$ & 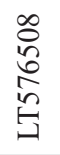 & 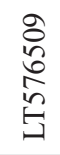 & $\begin{array}{l}a \\
\vec{n} \\
b \\
i n \\
\vdots \\
\omega\end{array}$ \\
\hline 总. & $\begin{array}{l}\hat{N} \\
\hat{\tilde{N}} \\
\tilde{\infty}\end{array}$ & $\bar{n}$ & $\begin{array}{l}\vec{\infty} \\
0 \\
\stackrel{+}{+} \\
\stackrel{\infty}{n}\end{array}$ & $\bar{n}$ & 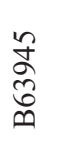 & $\begin{array}{l}\stackrel{+}{N} \\
\stackrel{N}{N} \\
\stackrel{D}{n}\end{array}$ & 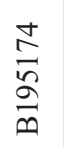 & $\begin{array}{l}\stackrel{\approx}{\approx} \\
\hat{\approx} \\
\frac{n}{n}\end{array}$ & 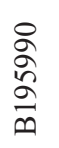 & 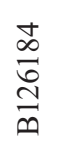 & $\frac{\stackrel{n}{a}}{\stackrel{a}{a}}$ & 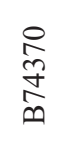 & $\begin{array}{l}\text { సे } \\
\text { ڤે } \\
\text { ஸे }\end{array}$ \\
\hline
\end{tabular}

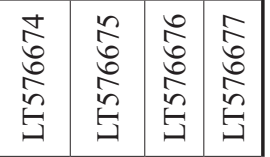

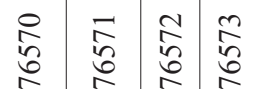

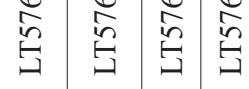

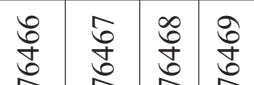

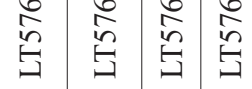

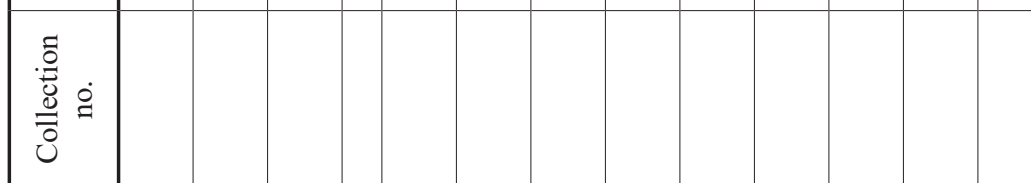

(2)

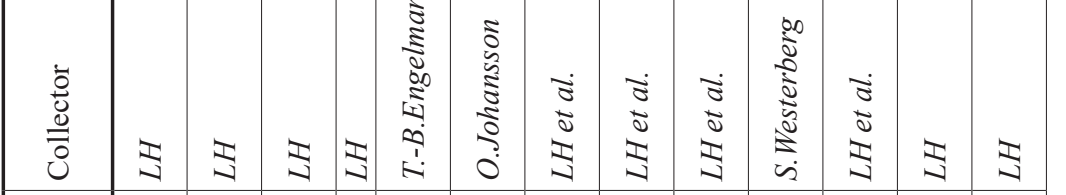

䒕

\begin{tabular}{|c|c|c|c|c|c|c|c|c|c|c|c|c|c|}
\hline 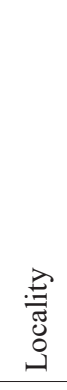 & 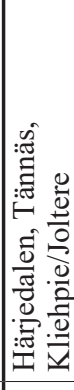 & 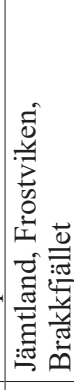 & 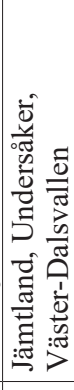 & 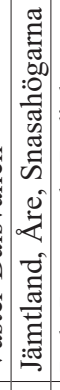 & 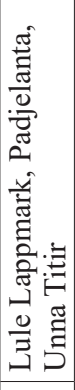 & 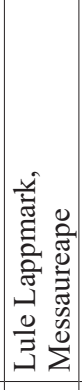 & 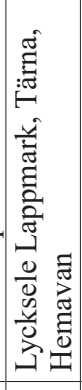 & 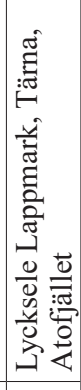 & 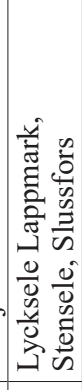 & 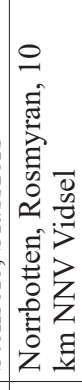 & 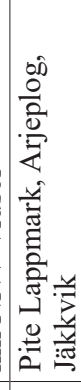 & 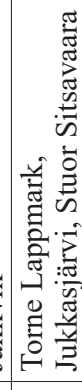 & 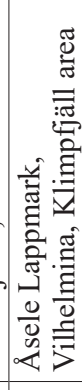 \\
\hline $\begin{array}{l}\text { 害 } \\
\text { 号 }\end{array}$ & 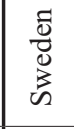 & 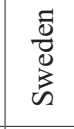 & 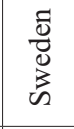 & $\left|\begin{array}{c}\tilde{z} \\
\bar{d} \\
\tilde{z} \\
\tilde{c}\end{array}\right|$ & 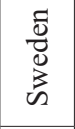 & 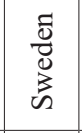 & 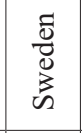 & $\begin{array}{l}\bar{\Xi} \\
\bar{d} \\
\vdots \\
\bar{n}\end{array}$ & 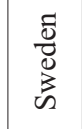 & $\begin{array}{l}\text { चี } \\
\overline{0} \\
\grave{\Delta}\end{array}$ & 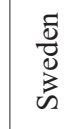 & 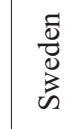 & 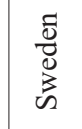 \\
\hline$\stackrel{0}{2}$ & $\underset{d}{~}$ & $\ddot{\approx}$ & $\hat{m}$ & $\infty$ & సે & o & & $\stackrel{\text { I }}{ }$ & & † & & f & \\
\hline
\end{tabular}

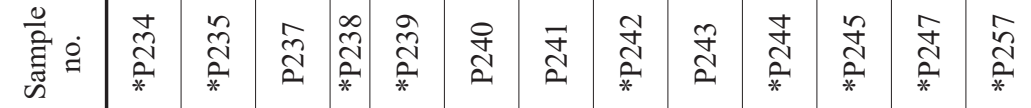

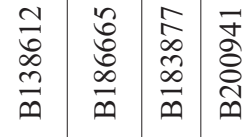

(x)

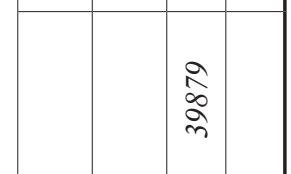

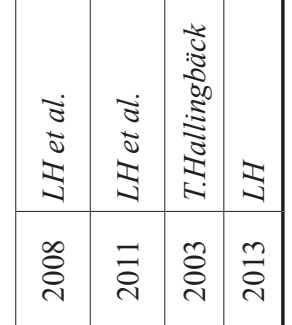

- 
based on the results of the present study. Detailed information on these specimens is available at: http:// herbarium.nrm.se/

\section{Molecular methods}

Total DNA was extracted using the DNeasy ${ }^{\circledR}$ Plant Mini Kit for DNA isolation from plant tissue (QIAGEN) or the KingFisher Duo magnetic particle processor and the KingFisher Pure DNA Plant Kit (Thermo Fisher Scientific). Double stranded DNA templates were prepared by polymerase chain reaction (PCR). PCR was performed using IllustraTM Hot Start Mix RTG (GE Healthcare) in a $25 \mu 1$ reaction volume according to the manufacturer's instructions.

Initially, variation in the nuclear internal transcribed spacers 1 and 2 (ITS) and a portion of glyceraldehyde 3-phosphate dehydrogenase $(g p d)$, and the plastid $a t p \mathrm{~B}-r b c \mathrm{~L}$ spacer $(a t b \mathrm{~B}-r b c \mathrm{~L}), r p l 16 \mathrm{G} 2$ intron $(r p l 16)$, the $r p s 4$ gene $+\operatorname{trnS}$ - rps 4 spacer $(r p s 4), \operatorname{trn} \mathrm{G}_{\mathrm{UCC}} \mathrm{G} 2$ intron $(\operatorname{trn} \mathrm{G})$, and $\operatorname{trn} \mathrm{L}_{\mathrm{UAA}}$ intron plus

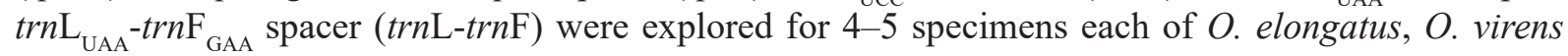
s. lat., and $O$. wahlenbergii. The three most variable ones, ITS, $\operatorname{trn} \mathrm{G}$, and $r p s 4$ were selected for the investigation. ITS was amplified with the primers '18SF' and '26SR' (Rydin et al. 2004), in a few cases with the internal primers '5.8F-Chrys' (Howis et al. 2009) and '5.8SRPEny' (Nylinder et al. 2013), trnG with the primers 'trnGf' and 'trnGr' (Pacak \& Szweykowska-Kulińska 2000), and rps4 with 'rps5F' (Nadot et al. 1994) and 'trnS' (Souza-Chies et al. 1997). For all three markers the following PCR program was used: $5 \mathrm{~min}$ at $95^{\circ} \mathrm{C}$ followed by 4 cycles of $30 \mathrm{sec}$ at $95^{\circ} \mathrm{C}, 30 \mathrm{sec}$ at $57^{\circ} \mathrm{C}, 1 \mathrm{~min}$ at $72^{\circ} \mathrm{C}$, 4 cycles of $30 \mathrm{sec}$ at $95^{\circ} \mathrm{C}, 30 \mathrm{sec}$ at $55^{\circ} \mathrm{C}, 1 \mathrm{~min}$ at $72^{\circ} \mathrm{C}$ and $34 \mathrm{cycles}$ of $30 \mathrm{sec}$ at $95^{\circ} \mathrm{C}, 30 \mathrm{sec}$ at $57^{\circ} \mathrm{C}$, $1 \mathrm{~min}$ at $72^{\circ} \mathrm{C}$ and a final elongation step of $8 \mathrm{~min}$ at $72^{\circ} \mathrm{C}$.

Twenty $\mu 1$ of each amplified fragment were cleaned using a mixture of 20 units of Exonuclease I from E.coli and 4 units of FastAP TM Thermosensitive Alkaline Phosphatase (Fermentas LIFE SCIENCE), mixed and incubated at $37^{\circ} \mathrm{C}$ for $30 \mathrm{~min}$ and inactivated at $80^{\circ} \mathrm{C}$ for $15 \mathrm{~min}$. Cycle sequencing was performed using the ABI BigDye Terminator Kit (Applied Biosystems) according to the instructions on the kit (BDT ver. 3.1), and the sequencing products were cleaned using the DyeEx ${ }^{\circledR} 96$ Kit (QIAGEN). The same primers as for the initial PCR were used. Sequencing products were resolved on an ABI3130xl automated sequencer. Double stranded sequencing was performed.

\section{Sequence editing and analysis of molecular data}

Nucleotide sequence fragments were edited and assembled for each DNA region using PhyDE® 0.9971 (http://www.phyde.de/index.html). The assembled sequences were manually aligned in PhyDE®. Regions of partially incomplete data in the beginning and end of the sequences were identified and excluded from subsequent analyses. Gaps were coded as informative by simple indel coding (Simmons \& Ochoterena 2000), using SeqState (Müller 2005). The sequence alignments used in the analyses are available on request. European Nucleotide Archive (EMBL-ENA) accession numbers are listed in Table 1.

Paralogous ITS haplotypes are rarely encountered in bryophytes (but see Košnar et al. 2012). However, the ITS chromatograms generated in this study did not show 'messy' patterns or noise that could suggest paralogy, and the 5.8S gene was invariable among the samples (cf., Shaw et al. 2002; Feliner \& Rosselló 2007). The revealed ITS variation is thus interpreted as being among homologous haplotypes.

The program TCS (Clement et al. 2000) with a cut-off level of 0.95 was used to evaluate relationships among specimens in a haplotype context. Reticulation was revealed in the haplotype networks based on either ITS or chloroplast data. Because reticulation occurs a split network was computed with the NeighborNet (NN) method as implemented in SplitsTree 4.12.6 (Huson \& Bryant 2006) to visualize similarities or relationships among samples. A Jacknife analysis (1000 replications) was performed with 
the program TNT (Goloboff et al. 2003) to test whether supported lineages exist among the studied Oncophorus species in a phylogenetic tree context. ITS and chloroplast data were analysed separately, since both visual inspection of the split networks, Jacknife trees, and the ILD test (Farris et al. 1995; 200 replicates, $\mathrm{p}=0.005$ ) indicated that the two are incongruent.

\section{Morphological study and analysis of measurements}

After the molecular relationships among the studied $O$. elongatus, $O$. wahlenbergii, and $O$. virens $\mathrm{s}$. lat. specimens had been clarified, the morphology of selected specimens belonging to the distinguished molecular entities was studied. Earlier studies (e.g., Frahm et al. 1998) based only on morphology had clearly separated $O$. elongatus $-O$. wahlenbergii from $O$. virens s. lat., but had failed to correctly identify the further morphological entities distinguished by the molecular study. Therefore, an approach including both standard comparisons of qualitative and quantitative characters and the quantification of vegetative leaf size and especially leaf cell size and shape was used. Since vegetative leaves are invariably present in a plant it was expected that the latter approach, which had not been explored previously within Oncophorus, would reveal quantitative differences supporting the molecularly recognized entities.

Among molecularly identified $O$. virens s. lat., the two main entities $O$. virens s. str. and $O$. integerrimus Hedenäs (sp. nov.; see below) were sampled with 10 specimens each. The seemingly more heterogeneous $O$. elongatus was sampled with 18 specimens and $O$. wahlenbergii with 17 specimens. These 17 specimens included those belonging to the two small, molecularly well-supported $O$. wahlenbergii clades B and C in Fig. 1. The morphologically sampled specimens are indicated with an asterisk (*) in Table 1. For each of these specimens, three vegetative leaves were sampled from two shoots (2 leaves from one stem and 1 from the other, to avoid sampling all leaves from an untypical shoot for the specimen). For each leaf, length and maximal width was measured, and the length, width, and length-towidth ratio of 20 cells in the upper acumen, 20 in the lower acumen, and 20 in the sheathing basal lamina were recorded. Temporary images of the leaves were taken through an Olympus BX43 microscope using an Olympus SC50 digital camera and the Olympus cellSens Standard 1.13 software (Olympus Corporation) for automatic and continuous image stacking. Measurements were then made from these leaf and cell images, using the Olympus cellSens Standard 1.13 software.

Comparisons among the four entities within O. elongatus-O. wahlenbergii and between the two within $O$. virens s. lat., respectively, are based on two approaches. First, the cell measurements were compared between the entities within each of the two groups. Shapiro Wilks W-test (normality) and Levenes test (homogeneity of variance) were both statistically significant, and inspection of the distributions of residuals in preliminary ANOVAs (normality) showed that the data do not meet the criteria of normality and homogeneity of variance. Thus, for $O$. elongatus-O. wahlenbergii the nonparametric Kruskal-Wallis test for multiple comparisons and for O. virens s. lat. the nonparametric Mann WhitneyU-test for comparing two groups were used to compare the cell measurements among or between the entities, respectively. Second, the measurements of the individual leaves (length, width, and the mean cell length, cell width, and cell length-to-width ratio, at each of the three positions in the leaf; in total 11 parameters) were subjected to a Principal Component Analysis (PCA) to see whether the combined information corresponds with the molecularly identified entities. All statistical calculations were made in STATISTICA 12 (StatSoft 2013).

\section{Herbarium data}

Herbarium acronyms follow Index Herbariorum (Thiers continuously updated). For specimens citations, double quotes "..." indicates that citation is exactly as on label; square brackets $[\ldots]$ indicates that information is interpreted from label data. 


\section{Results}

\section{Molecular relationships}

The total number of aligned ITS sites in the 100 studied Oncophorus specimens, and outgroup of two Cynodontium strumiferum and two Rhabdoweisia fugax specimens, after deletion of regions at the beginnings and ends that were incomplete for some specimens, was 1022. Of these, 212 sites were variable (122 in the species complexes around Oncophorus virens and O. wahlenbergii), with $95.8 \%$ (95.1\%) of the variable ones parsimony-informative; 181 (85) indels were present, with $93.9 \%(96.5 \%)$ informative. For $\operatorname{trn} \mathrm{G}$ the length was 618, 91 (63) were variable, and 96.7\% (95.2\%) of these were parsimony-informative; 25 (10) indels with $92 \%$ (90\%) informative. For rps 4 the length was 628,73 (35) were variable, and $98.6 \%(97.1 \%)$ of these were parsimony-informative; 4 (3) indels with $100 \%$ $(100 \%)$ informative. The sequence lengths for the species were: Oncophorus crispifolius $(\mathrm{n}=2): 827$ (ITS), 574 (trnG), 621 (rps4); O. dendrophilus (2): 818, 581, 628; O. elongatus (24): 812-823, 588, 621; O. rauei (2): 819-823, 579, 610; O. virens (22): 835-838, 578-596, 620; O. wahlenbergii (22): 803-826, 581-582, 612; O. integerrimus sp. nov. (26): 837-840, 579, 627; Cynodontium strumiferum (2): 773, 576, 621; Rhabdoweisia fugax (2): 782-784, 571, 621.

The NN split networks and the corresponding haplotype networks identified by TCS are shown with indications of branches having Jacknife support of at least 75 in Fig. 1. Both the nuclear and plastid data provide support for the three O. elongatus entities A-C, except that $\mathrm{P} 218$ belongs to B according to the ITS data and A in the plastid data. Support is provided for the three O. wahlenbergii entities A-C. Both data sets also support the two main entities $O$. virens and $O$. integerrimus (sp. nov.; see below) in $O$. virens s. lat., with additional differentiation within $O$. virens s. str., although the latter is incongruent between the two data sets except for $O$. virens $\mathrm{B}$, that differs from $O$. virens $\mathrm{A}$ in 2 (ITS) or 3 mutations (Fig. 1).

\section{Morphological evaluation}

No differences could be found between $O$. wahlenbergii A and C (not shown), and these are therefore merged in the following $(O$. wahlenbergii AC). The PCA based on leaf and leaf cell measurements revealed that $O$. elongatus differs from $O$. wahlenbergii AC, with some overlap between the two (Fig. $2 \mathrm{~A}$ ). The differentiation is along PCA axis 2, showing that leaf length and width, as well as the width of cells in the apical and middle portions of the leaves, are most important in explaining this separation (Fig. 2A:1). Oncophorus elongatus and $O$. wahlenbergii AC differ from each other in five out of nine individual leaf lamina cell sizes or length-to-width ratios, whereas $O$. wahlenbergii $\mathrm{B}$ is sometimes most similar to either O. elongatus or $O$. wahlenbergii $\mathrm{AC}$, sometimes intermediate between these, or its mean values are larger or smaller than those of both the other two (Table 2; cf., Fig. 2A). Also O. virens and O. integerrimus sp. nov. differ from each other in the PCA based on these parameters, again with a small overlap (Fig. 2B). The main differentiation is along PCA axis 1, and leaf length, length of the apical leaf lamina cells and width of the middle ones, as well as the length-to-width ratio of the apical and middle lamina cells contribute most to this pattern (Fig. 2B:1). These two species differ in all cell measurements (Table 3). Finally, despite the found statistical differences, which are based on large numbers of measurements from molecularly identified groups, the overlap among O. elongatus-O. wahlenbergii entities and between $O$. virens-O. integerrimus sp. nov. in individual characters is large (Supplementary file: Figs S1, S2).

\section{Geographical distribution and habitat}

The distribution of the four Scandinavian Oncophorus species is mapped in Fig. 3, based on the material in S. All species can grow in several habitat types, but each species is most commonly found in one or two of these (Fig. 4). Three members of the genus (O. elongatus, $O$. wahlenbergii, O. integerrimus sp. nov.) 


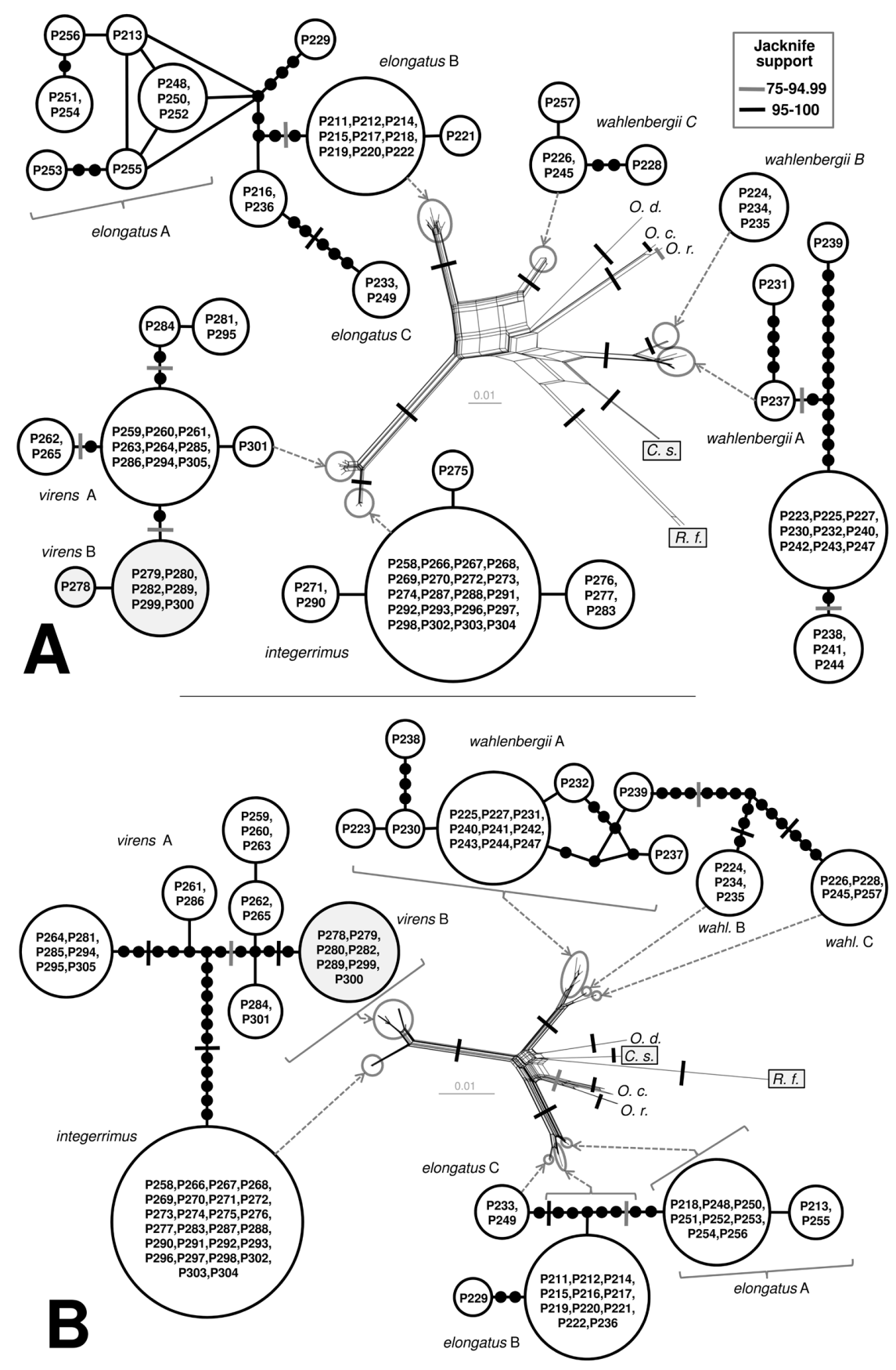

Fig. 1. NeighborNet split network for the 104 specimens studied, based on ITS (A) and the chloroplast markers trn $\mathrm{G}$ and rps4 (B): Oncophorus crispifolius (O.c., 2 specimens), O. dendrophilus (O.d., 2), O. elongatus (24), O. rauei (O.r., 2), O. virens (22), O. wahlenbergii (22), O. integerrimus Hedenäs sp. nov. (26), and outgroup (light grey boxes: C.s. $=$ Cynodontium strumiferum, $2 ;$ R.f. $=$ Rhabdoweisia fugax, 2). Haplotype networks based on all samples of $O$. elongatus, $O$. virens, $O$. wahlenbergii, and O. integerrimus Hedenäs sp. nov. are shown distal to 'branches' identified in the split network to show the full resolution among haplotypes. Circle size in the haplotype networks is proportional to the number of sampled populations of a certain haplotype, and sample numbers are explained in Table 1. Circles connected by a line differ in a single mutational difference; black dots indicate 'missing' haplotypes. Jacknife support values of 75-94.99 and 95-100 are indicated by transverse grey and black lines, respectively. 


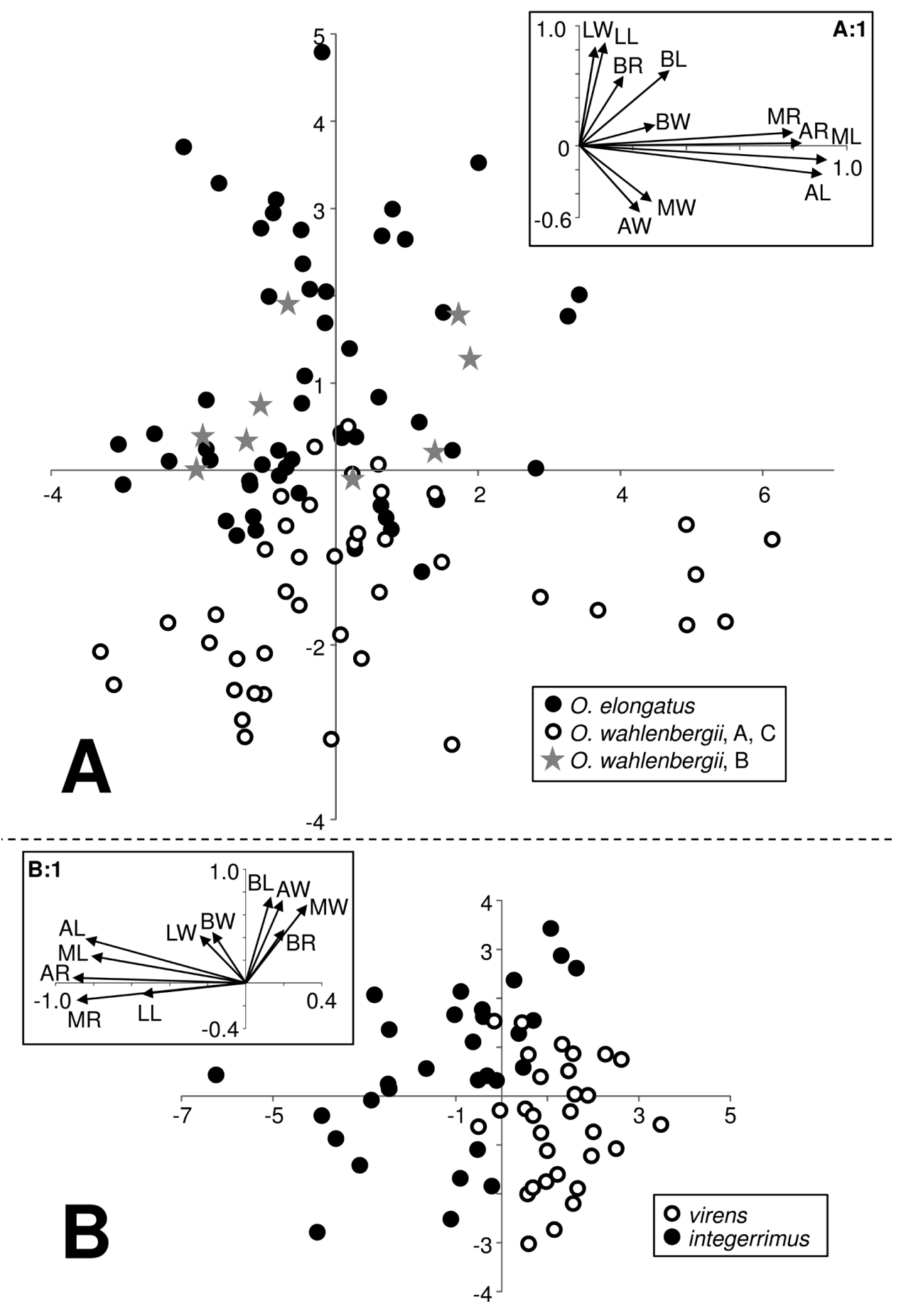

Fig. 2. The positions of three leaves from each of 18 molecularly identified specimens of $O$. elongatus, 14 of $O$. wahlenbergii A and C, and 3 of $O$. wahlenbergii B (cf. Fig. 1) (A), and of 10 specimens of $O$. virens and 10 of $O$. integerrimus Hedenäs sp. nov. (B), along the first two axes in a PCA. The PCA is based on each leaf's length (LL), width (LW), and leaf lamina cell length, width, and length/width ratio in the apical (AL, AW, AR), middle (ML, MW, MR), and sheathing basal (BL, BW, BR) lamina. Cell measurements are the mean values of 20 cells per position in each leaf. Axes 1 (x) and 2 (y) explain $30.69 \%$ and $25.24 \%$ of the variation in A, and $32.56 \%$ and $22.01 \%$ of the variation in B. Insert diagrams A:1 and B:1 depict explanatory factors in the plane of these two axes. 
Table 2. Means plus standard errors for cell measurements in the acumen (20 cells per leaf), in mid-leaf (20), and in the sheathing base (20) from three leaves in each of 18 specimens of Oncophorus elongatus, three specimens of $O$. wahlenbergii $\mathrm{B}$, and 14 specimens of $O$. wahlenbergii $\mathrm{A}$ and $\mathrm{C}$ (AC). The number of measured cells at each position, n, is indicated after the species. Significant pair-wise differences between species revealed by the Kruskal-Wallis test are indicated by different letters appended after the values in the respective columns, for the Bonferroni corrected $p$ values corresponding with $p<0.05$.

\begin{tabular}{|l|c|c|c|}
\hline Position; measurement & elongatus (1080) & wahl. B (180) & wahl. AC (840) \\
\hline Acumen; length (AL) & $14.6(0.1) \mathrm{a}$ & $14.8(0.4) \mathrm{a}$ & $17.3(0.2) \mathrm{b}$ \\
\hline Acumen; width (AW) & $10.8(0.1) \mathrm{a}$ & $11.4(0.1) \mathrm{b}$ & $12.3(0.1) \mathrm{c}$ \\
\hline Acumen; AL/AW ratio (AR) & $1.40(0.02)-$ & $1.31(0.03)-$ & $1.45(0.02)-$ \\
\hline Mid-leaf; length (ML) & $17.4(0.2) \mathrm{a}$ & $17.9(0.4) \mathrm{ab}$ & $19.4(0.2) \mathrm{b}$ \\
\hline Mid-leaf; width (MW) & $10.4(0.0) \mathrm{a}$ & $10.1(0.1) \mathrm{a}$ & $11.5(0.1) \mathrm{b}$ \\
\hline Mid-leaf; ML/MW ratio (MR) & $1.72(0.02)-$ & $1.84(0.05)-$ & $1.74(0.02)-$ \\
\hline Base; length (BL) & $51.1(0.5) \mathrm{a}$ & $55.3(1.1) \mathrm{b}$ & $47.5(0.5) \mathrm{c}$ \\
\hline Base; width (BW) & $10.2(0.1) \mathrm{a}$ & $9.5(0.1) \mathrm{b}$ & $10.0(0.1) \mathrm{ab}$ \\
\hline Base; BL/BW ratio (BR) & $5.20(0.06) \mathrm{a}$ & $6.07(0.16) \mathrm{b}$ & $4.87(0.06) \mathrm{a}$ \\
\hline
\end{tabular}

Table 3. Means plus standard errors for cell measurements in the acumen (20 cells per leaf), in mid-leaf (20), and in the sheathing base (20) from three leaves in each of ten specimens of Oncophorus virens and $O$. integerrimus Hedenäs sp. nov. The number of measured cells at each position, $\mathrm{n}$, is indicated after the species. Significant differences between species revealed by the Mann-Whitney U-test are indicated by different letters appended after the values in the respective columns, for the Bonferroni corrected $p$ values corresponding with $\mathrm{p}<0.05$.

\begin{tabular}{|l|c|c|}
\hline Position; measurement & virens (600) & integerrimus (600) \\
\hline Acumen; length (AL) & $13.7(0.2) \mathrm{a}$ & $16.3(0.2) \mathrm{b}$ \\
\hline Acumen; width (AW) & $10.6(0.1) \mathrm{a}$ & $9.6(0.1) \mathrm{b}$ \\
\hline Acumen; AL/AW ratio (AR) & $1.34(0.02) \mathrm{a}$ & $1.76(0.03) \mathrm{b}$ \\
\hline Mid-leaf; length (ML) & $14.2(0.2) \mathrm{a}$ & $16.1(0.2) \mathrm{b}$ \\
\hline Mid-leaf; width (MW) & $9.9(0.1) \mathrm{a}$ & $8.5(0.1) \mathrm{b}$ \\
\hline Mid-leaf; ML/MW ratio (MR) & $1.48(0.02) \mathrm{a}$ & $1.97(0.03) \mathrm{b}$ \\
\hline Base; length (BL) & $48.0(0.6) \mathrm{a}$ & $41.0(0.5) \mathrm{b}$ \\
\hline Base; width (BW) & $9.6(0.1) \mathrm{a}$ & $9.2(0.1) \mathrm{b}$ \\
\hline Base; BL/BW ratio (BR) & $5.27(0.08) \mathrm{a}$ & $4.67(0.07) \mathrm{b}$ \\
\hline
\end{tabular}



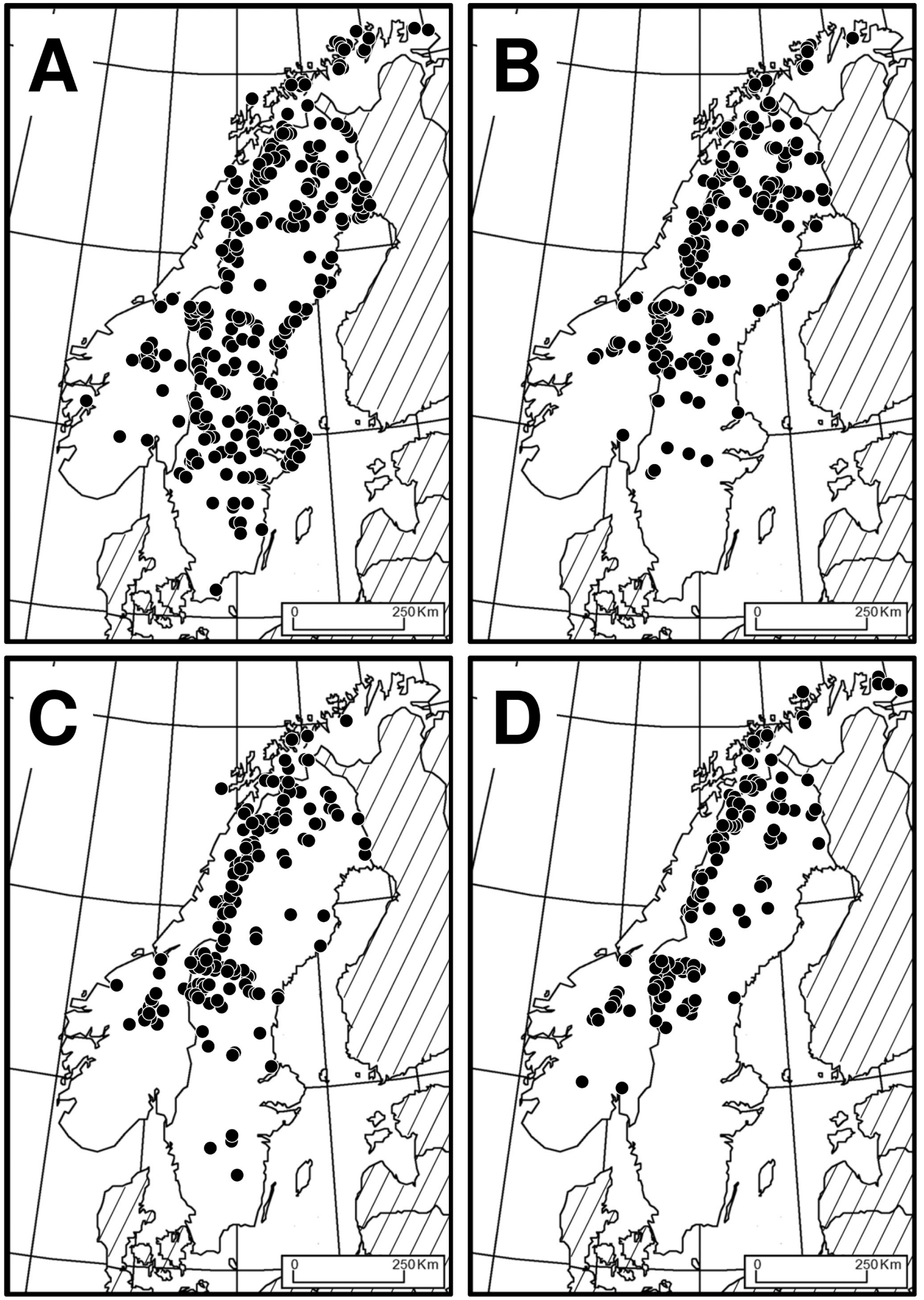

Fig. 3. Geographical distributions in Scandinavia. A. Oncophorus elongatus $(\mathrm{n}=459)$. B. O. wahlenbergii $(\mathrm{n}=333)$. C. $O$. virens $(\mathrm{n}=361)$. D. O. integerrimus Hedenäs sp. nov. $(\mathrm{n}=247)$. The distribution maps are based on the $\mathrm{S}$ material for which geographical origin could be determined. 


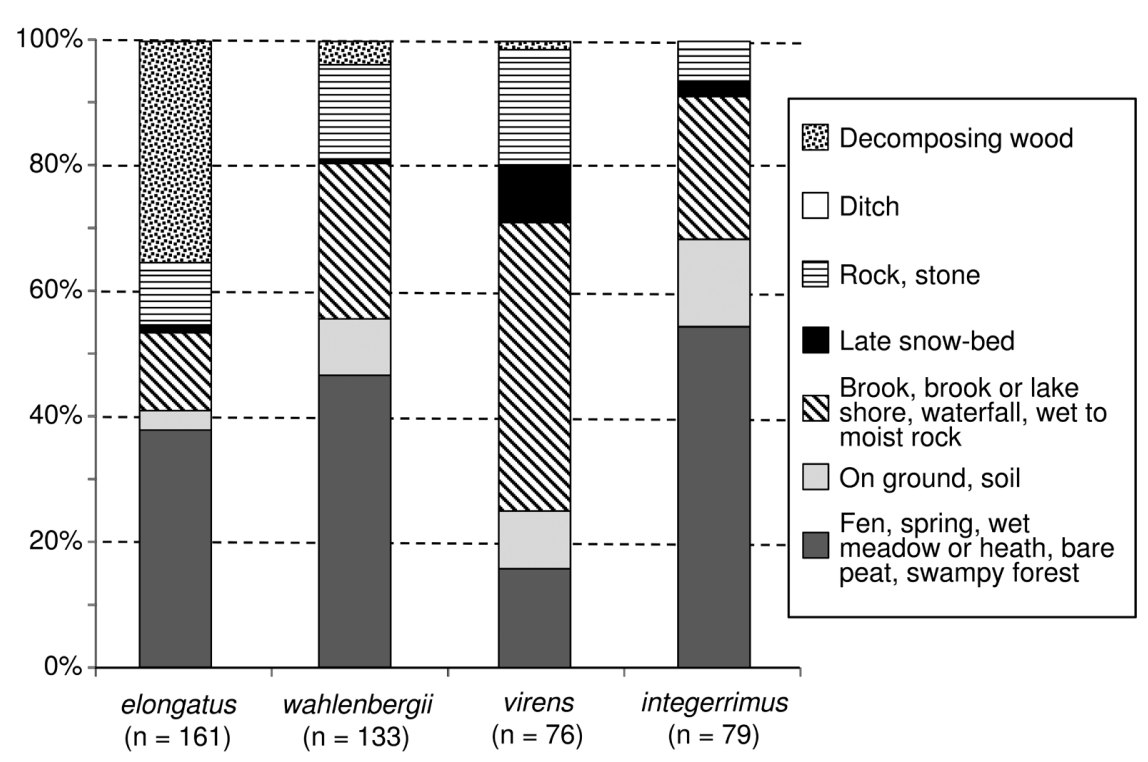

Fig. 4. Habitat preferences of Oncophorus elongatus, O. wahlenbergii, O. virens, and O. integerrimus Hedenäs sp. nov. in Scandinavia, based on label information from studied material in S.
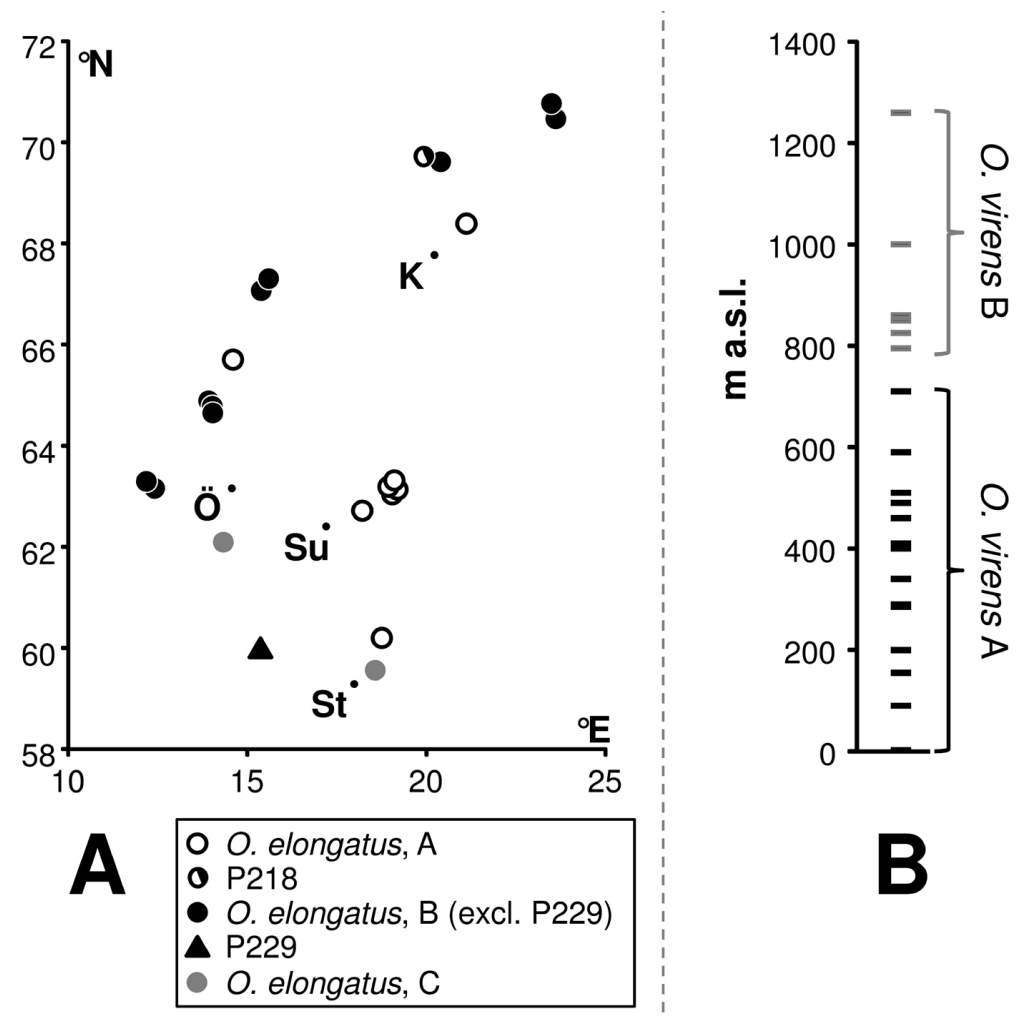

Fig. 5. A. Latitudinal and longitudinal distribution of Oncophorus elongatus samples belonging to different haplotypes or groups of haplotypes (cf., Fig. 1) based on ITS and plastid (trnG, rps4) data. Sample P218 is related to O. elongatus B according to ITS data and O. elongatus A according to plastid data (Fig. 1). The positions of the Swedish towns Kiruna (K), Stockholm (St), Sundsvall (Su), and Östersund (Ö) are indicated as references. B. Elevational distribution of the molecularly sampled Oncophorus virens A and B (P278-P280, P282, P289, P299, P300) in Scandinavia. 
have between 40 and $55 \%$ of their recorded occurrences in fens, springs, wet meadows and similar habitats. In addition, $35 \%$ of the finds of $O$. elongatus are from decomposing wood, an unimportant habitat for the other species, and for $O$. wahlenbergii and $O$. integerrimus sp. nov. $20-25 \%$ of the records are from shores of brooks and lakes, wet rocks, and similar habitats. Shores and wet rocks are the most important habitats for $O$. virens, which has more than $45 \%$ of its records there. This species is the only one with a significant number of occurrences in late snow-beds.

Within O. elongatus, the molecular differentiation corresponds with a geographic pattern. Samples from the lowlands and along the Bothnian coast mostly belong to O. elongatus A, whereas samples from the mountain range and the Norwegian coast are predominantly O. elongatus B (Fig. 5A). No such geographic pattern was found within the other species. Within $O$. virens, on the other hand, we find a very clear differentiation between low (O. virens A) and high (B) elevation haplotypes (Fig. 5B).

\section{Key to Scandinavian Oncophorus species}

1. Stem leaf margin plane throughout; alar cells not or weakly differentiated from other basal cells ...2

- Stem leaf margin at least partly distinctly recurved in lower leaf; alar cells well differentiated .......3

2. Lamina of basal, sheathing leaf portion in its middle and lower portions with long and narrow cells along margin; margin and often back of costa in upper (10-)25-35(-50)\% of many leaves denticulate or dentate, often sharply so, rarely with only a few leaves having scattered obtuse teeth above. Vegetative leaves $2.5-6.4 \times 0.4-1.2 \mathrm{~mm}$

1. O. elongatus (I.Hagen) Hedenäs

- Lamina of basal, sheathing leaf portion with quadrate to elongate-rectangular cells extending down along margin (from spreading lamina); margin and back of costa smooth, with an occasional and mostly obtuse and irregular denticle (mostly close to leaf apex), or sometimes with projecting cell walls. Vegetative leaves $1.4-4.4 \times 0.3-0.8 \mathrm{~mm}$ 2. O. wahlenbergii Brid.

3. Leaf margin in acumen and often down to mid-leaf regularly to irregularly dentate or coarsely denticulate with mostly sharp and often some double teeth, strong teeth often directed forwards, occasional leaves less distinctly dentate. Dry leaves with acumen from above sheathing base erect and tightly incurved to spreading, above strongly twisted 3. O. virens (Hedw.) Brid.

- Leaf margin in acumen entire or indistinctly and obtusely denticulate, occasionally distinctly denticulate close to leaf apex. Dry leaves with acumen from above sheathing base erect-patent to spreading and loosely incurved or curved upwards, upper acumen loosely but relatively strongly twisted 4. O. integerrimus Hedenäs sp. nov.

\section{Taxonomy}

For all species, the total number of studied specimens is indicated in Fig. 3, and a selection of studied specimens is found in Table 1.

Class Bryopsida Pax (Pax 1900)

Subclass Dicranidae Doweld (Doweld 2001)

Order Dicranales M.Fleisch. (Fleischer 1920)

Family Oncophoraceae M.Stech (Stech \& Frey 2008)

Genus Oncophorus Brid. (von Bridel 1826)

Bryologia Universa 1: 389 (von Bridel 1826). - Type: Oncophorus virens (Hedw.) Brid. 


\section{Oncophorus elongatus (I.Hagen) Hedenäs}

Fig. 6

Lindbergia 30: 36 (Hedenäs 2005). - Oncophorus wahlenbergii var. elongatus I.Hagen, Tromsø Museums Aarshefter 21-22: 13 (Hagen 1899). - Cynodontium wahlenbergii var. elongatum (I.Hagen) Mönk., Die Laubmoose Europas: 195 (Mönkemeyer 1927). - Type: "Norway. Nordland, Saltdalen, Rognanfjeld, $67^{\circ} 6^{\prime}$ N, 600 m asl, 21 July 1889, R. E. Fridtz" (lecto-: O!, designated by Hedenäs 2005).

\section{Description}

Plants up to ten $\mathrm{cm}$ high, mostly in loose tufts, green or yellow-green. Stem with large central strand, a cortex plus epidermis of 1-2 layers of incrassate cells, epidermis not differentiated as a hyalodermis; axillary hairs with 2-8-celled, hyaline upper portion, $8-10 \mu \mathrm{m}$ wide, basal 1-2 cells rectangular, brown; rhizoids strongly branched, red-brown, smooth, in leaf axils or shortly above. Leaves $2.5-6.4 \times 0.4-$ $1.2 \mathrm{~mm}$, when moist from strongly sheathing base erect, or erect-patent to spreading and straight or slightly curved, when dry with middle leaf spreading and gradually curved upwards or upwards-inwards and curled or slightly curled, from oblong-obovate or ovate sheathing portion (narrowed or strongly narrowed towards insertion) with long and almost linear, gradually narrowing upper portion, apex long- or very long-acuminate; leaf margin plane throughout, below entire, in upper 20-25(-35)\% partly irregularly dentate or denticulate with sharp forwards-directed teeth, or sometimes relatively weakly denticulate, or some leaves almost entire and other leaves with scattered teeth along upper margin, teeth single or occasionally double, sometimes with cell walls projecting along upper margin, margin varying from unistratose to bistratose; costa 53-125 $\mu \mathrm{m}$ wide near base, with dorsal and ventral epidermis cells slightly widened but incrassate, one layer of large guide cells, 1-3 layers of ventral stereids and 2-3(-4) layers of dorsal stereids, sometimes with mammillae, or erect to forwards-directed teeth on upper back; lamina cells in acumen incrassate or strongly so, 10-21 $\times 9-14 \mu \mathrm{m}, 0.9-2.0$ times as long as wide, in mid-leaf incrassate or strongly so, $11-29 \times 8-13 \mu \mathrm{m}, 1-3$ times as long as wide, and in sheathing lamina strongly incrassate and eporose or indistinctly porose, $36-88 \times 8-14 \mu \mathrm{m}, 3.5-9.1$ times as long as wide, transition between mid-leaf and basal cells gradual, due to relatively long mid-leaf cells and relatively short basal cells, lamina of basal, sheathing portion of leaf in middle and below with long and narrow cells also along margin; alar cells undifferentiated or a few cells slightly wider than other basal cells and sometimes brownish, unistratose, not or shortly and narrowly decurrent. Perigonia lateral on stem, not or shortly stalked, antheridia protected by oblong-triangular perigonial leaves having obtuse to narrowly acuminate acumen. Inner perichaetial leaves 5.36-7.14 mm long, lower 26-42\% oblong and broadly sheathing, above suddenly narrowed to long, narrow acumen. Seta tall, (6-)12-25 mm; capsule obloid, slightly curved, with distinct struma, $0.9-1.4 \times 0.5-1.0 \mathrm{~mm}, 1.3-2.1$ times as long as broad, more or less orthogonal; exothecial cells slightly incrassate, mostly slightly collenchymatous; stomata ovate-pored, surrounded by indistinctly radially arranged cells, near base of capsule; peristome orange-red, teeth cleft or perforated to one- or two-thirds down, with longitudinal rows of pits on outside; spores $23-30 \mu \mathrm{m}$, very finely rough.

\section{Remarks}

Well-developed O. elongatus has very long leaves, which are narrow above their sheathing base. In oceanic portions of the Scandinavian mountain range and along the Norwegian coast the species often grows in open fens or wet heaths or meadows and then the leaves are mostly spreading and give the plants a very characteristic appearance. This is the kind of plants that made Hagen (1899) distinguish $O$. wahlenbergii var. elongatus and Hedenäs (2005) raise it to the species level. However, molecular data show that this species is variable both molecularly and morphologically and with the present circumscription, the species includes also plants with different leaf orientations and from different habitats than the plants originally referred to it. Morphologically, this species differs from $O$. wahlenbergii in that the middle and basal portions of the basal, sheathing lamina have long and narrow cells also along its margin. In 

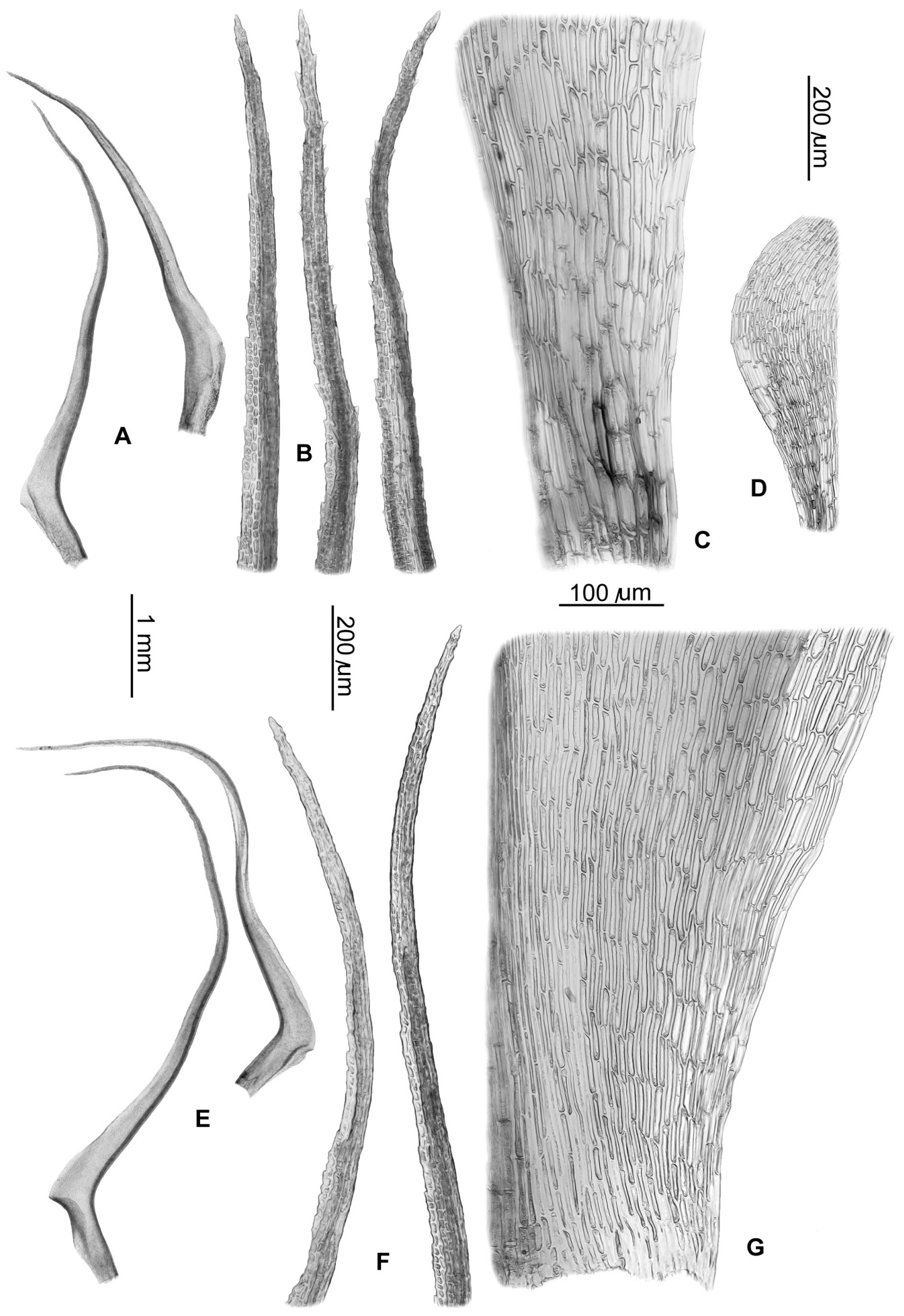

Fig. 6. A-D. Oncophorus elongatus A (specimen P251; cf., Table 1). E-G. O. elongatus B (specimen P221, cf. Table 1). A, E. Stem leaves. B, F. Upper leaf acumen. C, G. Marginal and alar portions of sheathing leaf base (margin to the right). D. Portion of leaf at widest point, showing the flat margin. 
addition, $O$. elongatus has longer vegetative leaves than $O$. wahlenbergii, and some or many leaves have almost always got denticulate or sharply denticulate upper margins, often with denticles on the back of the costa also. Rarely some plants have only a few leaves with denticles along the margin, and their denticles are in addition scattered and obtuse. In such cases the cell pattern of the sheathing lamina can be used to distinguish the two species. As noted by Hedenäs (2005) the spore capsules of $O$. elongatus mature somewhat before those of $O$. wahlenbergii.

\section{Habitat and distribution in Scandinavia}

This species is most frequent in open wetlands and humid forests, where it is found on humus-rich substrates and decomposing wood (Fig. 4). It occurs also on rocks, wet rocks, and on shores. Oncophorus elongatus is the most frequent and widespread member of the genus in Scandinavia (Fig. 3A), and is the only member of the genus that is relatively frequent also in large portions of the southern third of Sweden.

\section{Oncophorus wahlenbergii Brid.}

Figs 7,8

Bryologia Universa 1: 400 (von Bridel 1826). - Dicranum wahlenbergii (Brid.) Schultz, Sylloge Plantarum Novarum 2: 149 (Schultz 1828). - Dicranum virens var. wahlenbergii (Brid.) Huebener, Muscologia Germanica: 231 (Hübener 1833). - Aongstroemia wahlenbergii (Brid.) Müll.Hal., Synopsis muscorum frondosorum omnium hucusque cognitorum 2: 610 (Müller 1851). - Cynodontium wahlenbergii (Brid.) Hartm., Handbok i Skandinaviens Flora, Ed. 10, 2: 113 (Hartman 1871). - Type: no potential type material is extant in B (cf., Frahm et al. 1998; Hedenäs 2005), and the typification will be dealt with separately (Hedenäs \& Ochyra, in prep.).

Dicranum homannii Boeck in Hartman, Handbok i Skandinaviens Flora, Ed. 2: 314. (Hartman 1832). - Type: [Norway] "Dicr. Homanni, Sp. nov. e Gudbrandsdal, dedit Boeck, lectum 1830 Jun. 1. Jul., Ahnfeldt" in Herbarium Claës Gustaf Myrin, in Herb. Hj. Möller (iso-: S-B231701!).

Oncophorus virens var. gracilis Broth., Acta Societatis pro Fauna et Flora Fennica 6 (4): 75 (Brotherus \& Saelan 1890). - Oncophorus wahlenbergii var. gracilis (Broth.) Arnell \& C.E.O.Jensen, Bihang till Kongliga Svenska Vetenskaps-Akademiens Handlingar 21 Afd. 3 (10): 52 (Arnell \& Jensen 1896). Cynodontium virens var. gracile (Broth.) Paris, Index Bryologicus Supplementum Primum 111 (Paris 1900). - Cynodontium wahlenbergii var. gracile (Broth.) Mönk., Die Laubmoose Europas: 195 (Mönkemeyer 1927). - Type: [Russia] "V. F. Brotherus M. F. E. 434. Oncophorus virens (Sw.) Brid. var. gracilis Broth., Lapponia murmanica, in ripa arenosa fluvii Varsina, Aug. 11, 1887, leg. V. F. B." (iso-: S-B234603!).

Oncophorus sardous Herzog (syn. nov.), Allgemeine Botanische Zeitschrift für Systematik, Floristik, Pflanzengeographie 16: 84 (Herzog 1910). - Type: [Italy] "Fl. v. Sardinien, Auf Baumstumpf im Steineichenwald under d. Tonneri, 1100 m., leg. Th. Herzog, 4.1904, Typus!”, S; reg. no. B107132 (holo-: JE, n.v.; iso-: S-B107132!, H, n.v.).

Oncophorus gracillimus Dixon, Records of the Botanical Survey of India 9 (5): 304. pl. 1: f. 1 (Dixon 1926). - Type: [India] "On wood, Kamri Pass \& Kishenganga Valley, India, 8,000 14,000 ft. alt., J. Garrett \& W. Lillie, Aug. 1924, Comm. D. Lillie (Herb. H. N. Dixon Ref. No. 1138)" (holo-: BM, n.v. - synonymized by Frahm et al. 1998).

\section{Description}

Plants from a few $\mathrm{mm}$ to several $\mathrm{cm}$ high, in loose tufts or dense cushions, green or yellow-green. Stem with large central strand, a cortex plus epidermis of 1-2 layers of incrassate cells, epidermis not differentiated as a hyalodermis; axillary hairs with (1-)2-4-celled, hyaline upper portion, 7-12 $\mu \mathrm{m}$ wide, basal 1-2 cells rectangular, hyaline or pale brown; rhizoids strongly branched, red-brown, 
smooth, in leaf axils or shortly above. Leaves $1.4-4.4 \times 0.3-0.8 \mathrm{~mm}$, when moist from sheathing base erect to spreading and straight or slightly curved, when dry with middle leaf spreading and gradually curved upwards-inwards and slightly curled or weakly curled, from oblong or slightly oblong-obovate sheathing portion (narrowed towards insertion) with narrowly triangular to almost linear upper portion, gradually narrowing upper portion, apex obtuse, acute, acuminate or narrowly acuminate; leaf margin plane throughout, below entire, above entire or with one or few occasional and indistinct, mostly obtuse teeth, especially close to leaf apex, sometimes with cell walls distinctly projecting along upper margin, margin varying from unistratose to bistratose; costa 31-88 $\mu \mathrm{m}$ wide near base, with dorsal and ventral epidermis cells slightly widened but incrassate, one layer of large guide cells, 1-2 layers of ventral stereids and 1-3 layers of dorsal stereids, sometimes with projecting cell walls or cell portions in upper costa; lamina cells in acumen incrassate, $10-33 \times 10-15 \mu \mathrm{m}, 0.9-2.4$ times as long as wide, in mid-leaf
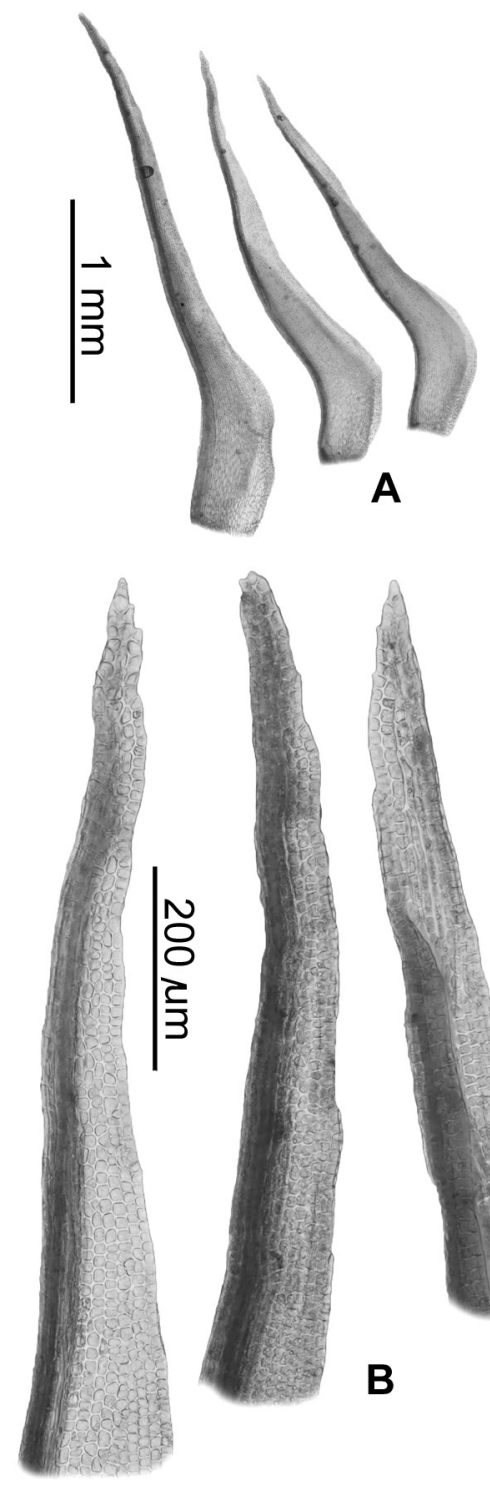
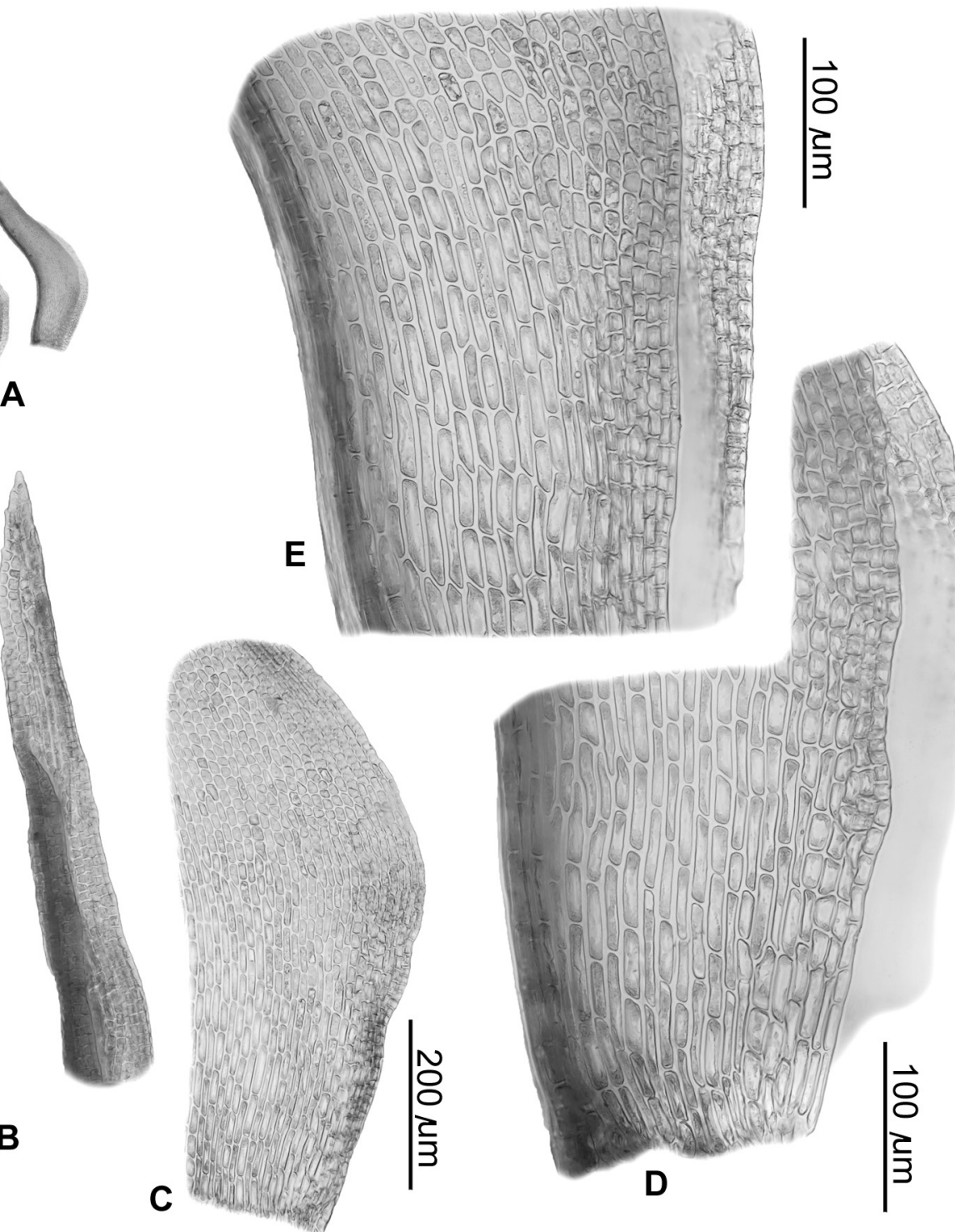

Fig. 7. Oncophorus wahlenbergii A (specimen P225; cf., Table 1). A. Stem leaves. B. Upper leaf acumen. C. Portion of leaf at widest point, showing the flat margin. D, E. Sheathing leaf portions, showing short marginal leaf cells (margin to the right) and, in $\mathrm{D}$, alar region. 


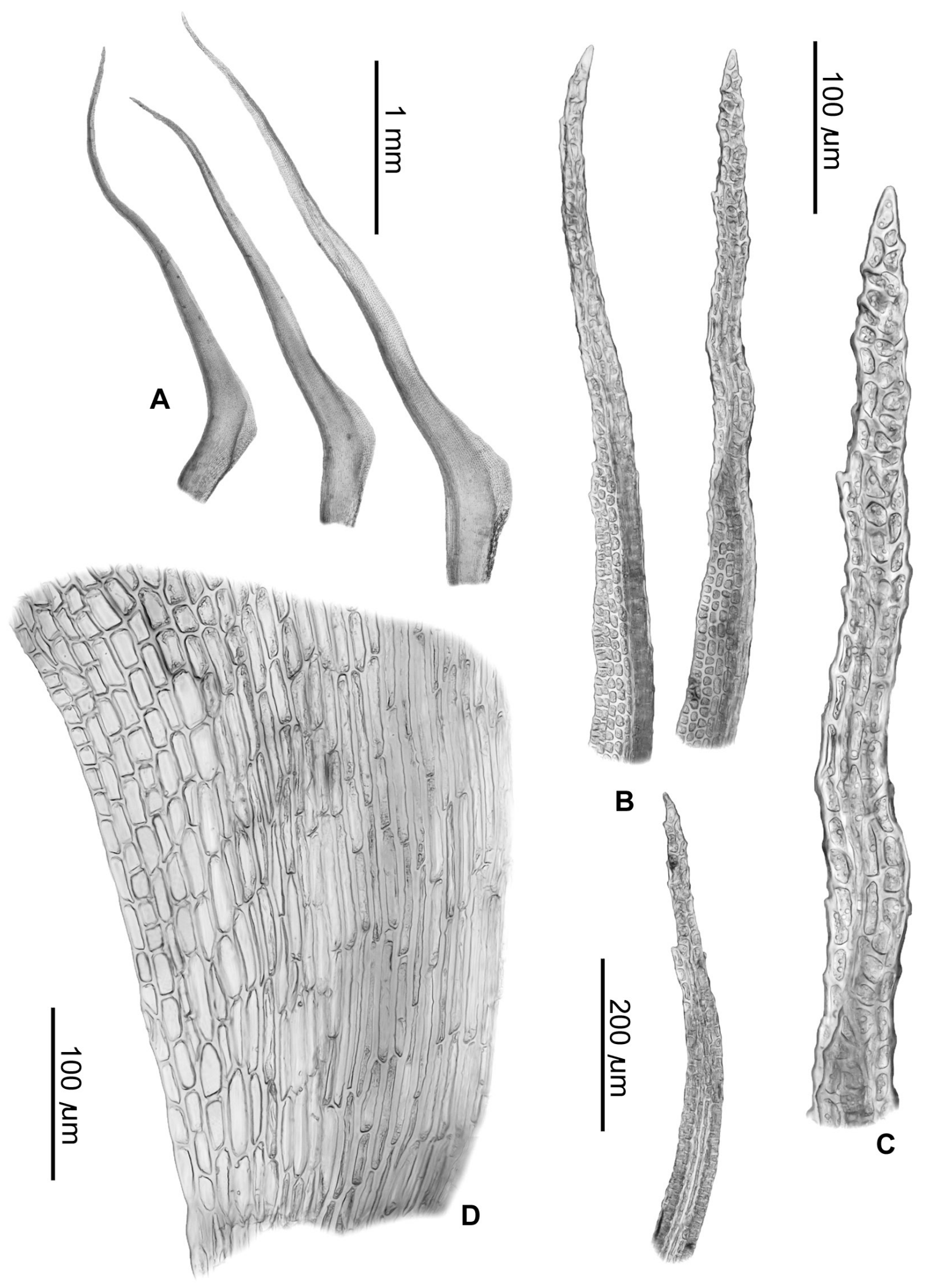

Fig. 8. Oncophorus wahlenbergii B (specimen P234; cf., Table 1). A. Stem leaves. B. Upper leaf acumen. C. Uppermost leaf acumen at higher magnification. D. Sheathing leaf portion, showing short marginal leaf cells and alar region (margin to the left). 
incrassate, $10-33 \times 8-17 \mu \mathrm{m}, 0.9-3.0$ times as long as wide, and in sheathing lamina strongly incrassate and eporose or indistinctly porose, 30-72 $\times 7-15 \mu \mathrm{m}, 3.4-8.3$ times as long as wide, transition between mid-leaf and basal cells gradual, due to relatively long mid-leaf cells and relatively short basal cells, lamina of basal, sheathing portion of leaf with quadrate or rectangular cells extending down along margin from spreading lamina; alar cells undifferentiated or a few cells wider than other basal cells, unistratose, not or shortly and narrowly decurrent. Perigonia lateral on stem, not or shortly stalked, antheridia protected by oblong-triangular perigonial leaves with obtuse or acute apex. Inner perichaetial leaves $2.73-4.24 \mathrm{~mm}$ long, lower $34-67 \%$ oblong and broadly sheathing, above suddenly narrowed to long, narrow acumen. Seta tall, 9-22 mm; capsule obloid, curved or slightly curved, with distinct struma, $0.5-1.3 \times 0.3-0.7 \mathrm{~mm}, 1.2-2.5$ times as long as broad, more or less orthogonal; exothecial cells incrassate, sometimes more strongly so in longitudinal walls, not or weakly collenchymatous; stomata sparse, ovate-pored or lacking pore, surrounded by radially arranged cells, near base of capsule; peristome red, teeth cleft or perforated to one-fourth or further down, with longitudinal rows of pits on outside; spores $21-29(-32) \mu \mathrm{m}$, finely rough.

\section{Remarks}

Oncophorus wahlenbergii is the smallest Scandinavian species. Contrary to O. elongatus it has quadrate or rectangular marginal cells in the middle and basal portions of the basal, sheathing lamina. In addition, its vegetative leaves are shorter than in O. elongatus, and in their upper potions the margins are entire or have occasionally one or a few indistinct teeth, especially close to the leaf apex. In some plants the cell walls project distinctly along the upper margin, and sometimes on the uppermost back of the costa.

\section{Habitat and distribution in Scandinavia}

Oncophorus wahlenbergii is most often found in open wetlands, but occurs also on soil, rocks, wet rocks, and on shores (Fig. 4). The species is widespread, but compared with O. elongatus it is much less common outside the mountain range and the far north (Fig. 3B), and has only been collected a few times in the southern third of Sweden.

\section{Nomenclatural notes}

The isotype of Oncophorus sardous Herzog (Herzog 1910) in S has plane leaf margins and no or few marginal teeth near the leaf apex, and several rows of short cells along the leaf margin in the sheathing lamina. Despite an earlier synonymisation with O. virens Hedw. (Frahm et al. 1998), the material unambiguously belongs to $O$. wahlenbergii Brid. The partly mammillose apical costa back and few marginal teeth or projecting cell walls remind about the molecularly identified $O$. wahlenbergii B (Fig. 1). However, since the geographical origin of the O. sardous type is distant from Scandinavia, further information is required to confidently judge its relationship with other $O$. wahlenbergii specimens.

The protologue of Oncophorus gracillimus Dixon (Dixon 1926) mentions entire or almost entire leaf margins, which indicates that the synonymy with $O$. wahlenbergii suggested by Frahm et al. (1998) is correct.

\section{Oncophorus virens (Hedw.) Brid.}

Fig. 9

Bryologia Universa 1: 399 (von Bridel 1826). - Dicranum virens Hedw., Species Muscorum Frondosorum: 142 (Hedwig 1801). - Aongstroemia virens (Hedw.) Müll.Hal., Synopsis Muscorum Frondosorum omnium hucusque Cognitorum 2: 609 (Müller 1851). - Cynodontium virens (Hedw.) Schimp., Corollarium Bryologiae Europaeae: 12 (Schimper 1856). - Type: no potential type material 
is extant in G (cf., Frahm et al. 1998; http://www.ville-ge.ch/musinfo/bd/cjb/hedwig/; accessed 4 Feb. 2016), and the typification will be dealt with separately (Hedenäs \& Ochyra in prep.).

Dicranum virens var. serratum Bruch \& Schimp., Bryologia Europaea 1: 119. 49g (fasc. 37-40. Mon. 13. 3g) (Bruch \& Schimper 1847). - Cynodontium virens var. serratum (Bruch \& Schimp.) Schimp., Corollarium Bryologiae Europaeae: 12 (Schimper 1856). - Oncophorus virens var. serratus (Bruch \& Schimp.) Braithw., The British Moss-Flora 1: 116 (Braithwaite 1883). - Type: "secus rivulos" (BM, n.v.; cf., below).

Aongstroemia curvicaulis Müll.Hal., Nuovo Giornale Botanico Italiano, n.s. 5 (2): 169 (Müller 1898). - Cynodontium curvicaule (Müll.Hal.) Paris, Index Bryologicus Supplementum Primum 111 (Paris 1900). - Oncophorus curvicaulis (Müll.Hal.) Broth., Die Natürlichen Pflanzenfamilien 1 (3): 319 (Brotherus 1901). - Type: "Bryotheca E. Levier. Oncophorus curvicaulis C. Müll., c.fr., Nuovo Giornale italiano 1898, p. 169 (sub. Angstroemia), China interior, provincia Schen-si sept., in monte Thae-peisan, Aug. 1896, legit Rev. Jos. Giraldi, determ. Prof. C. Müller sub. No. 1969” (lecto-: BM-000517729!, designated here).

Cynodontium bicolor Paris, Index Bryologicus Supplementum Primum: 111 (Paris 1900) (Aongstroemia bicolor Müll.Hal., Nuovo Giornale Botanico Italiano, n.s. 5: 170 (Müller 1898), nom. illeg.; later homonym). - Oncophorus bicolor (Paris) Broth., Die Natürlichen Pflanzenfamilien 1 (3): 319 (Brotherus 1901). - Type: "Bryotheca E. Levier. Oncophorus bicolor (C. Müll. sub Angstroemia, in N. Giorn. bot. ital. 1898, p. 170) Broth., China interior, provinc. SchenSi sept., in monte Tui-kio-san, 21 Sept. 1896, legit. Rev. Jos. Giraldi, determ. Dr. C. Müller n. 1970" (lecto-: BM-000517728!, designated here).

\section{Description}

Plants up to $8 \mathrm{~cm}$ high, usually in loose tufts, green or yellow-green. Stem with large central strand, a cortex plus epidermis of 1-2 layers of incrassate cells, epidermis not differentiated as a hyalodermis; axillary hairs with 2-4-celled, hyaline upper portion, $10-11 \mu \mathrm{m}$ wide, basal $1-2$ cells rectangular, hyaline; rhizoids strongly branched, red-brown, smooth, in leaf axils. Leaves $2.1-4.2 \times 0.6-1.0 \mathrm{~mm}$, when moist from sheathing base patent to spreading, straight or screwed, when dry above sheathing base erect and tightly incurved to spreading, above strongly twisted, from ovate or rounded oblong base with narrowly triangular acumen, apex acuminate to longly acuminate; leaf margin at least partly distinctly recurved in lower leaf, below entire, upper margin in all or many leaves regularly to irregularly dentate or coarsely and somewhat irregularly denticulate, sometimes only close to leaf apex but mostly in at least some leaves down to mid-leaf or almost so, teeth single or double, mostly sharp and when strong often directed forwards, margin varying from unistratose to bistratose; costa 83-120 $\mu \mathrm{m}$ wide near base, with dorsal and ventral epidermis, one layer of large guide cells, 1(-2) layers of ventral stereids and 2-3 layers of dorsal stereids; lamina cells in acumen incrassate, 6-30 $66-18 \mu \mathrm{m}, 0.5-3.3$ times as long as wide, in mid-leaf incrassate, $6-33 \times 6-15 \mu \mathrm{m}, 0.6-3.8(-4.2)$ times as long as wide, and in sheathing lamina incrassate and slightly porose, $20-109 \times 5-19 \mu \mathrm{m}, 1.6-15.8$ times as long as wide, transition between mid-leaf and basal cells relatively sudden, due to relatively short upper lamina cells and relatively long basal cells; alar cells differentiated, rectangular, slightly to strongly inflated and forming a diffusely delimited group of 3-4 cells wide and 2-4(-5) cells long, partly bistratose, decurrent. Perigonia lateral on stem, not stalked, antheridia protected by oblong perigonial leaves with "cut-off" or acute apex. Inner perichaetial leaves 3.27-6.18 mm long, lower 29-50\% oblong and broadly sheathing, above suddenly narrowed to long, narrow acumen. Seta tall, 12-29 mm; capsule cylindric or shortly so, curved or slightly curved, with distinct struma, $0.9-1.5 \times 0.5-0.6 \mathrm{~mm}, 1.6-2.9$ times as long as broad, more or less orthogonal to homotropus; exothecial cells incrassate or longitudinally incrassate, slightly collenchymatous or not; stomata ovate-pored, surrounded by radially arranged cells, near base of capsule; peristome red, teeth cleft or perforated to one-third or further down, with longitudinal rows of pits on outside; spores $23-38 \mu \mathrm{m}$, very finely rough. 


\section{Remarks}

This species is on the average weaker than $O$. integerrimus sp. nov. In addition, it differs by its usually strongly dentate leaf margins and in that dry leaves are more tightly incurved. Plants from high elevations, which can be molecularly differentiated from lowland ones, are often relatively small. However, neither this nor other morphological features consistently distinguish plants from different elevations.

\section{Habitat and distribution in Scandinavia}

Oncophorus virens occurs on rocks, especially wet rocks, and on brook and lake shores (Fig. 4). It is the only member of Oncophorus that is frequent in late snow-beds, and it grows also on soil and in open wetlands. This species is frequent mainly in the mountain range and the base- or calcium-rich lowland regions of northern Sweden (Fig. 3C). Like O. wahlenbergii, it has only been collected a few times in the southern third of Sweden.

\section{Nomenclatural notes}

Dicranum virens var. serratum Bruch \& Schimp. (Bruch \& Schimper 1847) should differ from Oncophorus virens (Hedw.) Brid. var. virens in having strongly serrate leaf margins (Bruch et al. 18361851). However, since $O$. virens has serrate to strongly serrate upper leaf margins, the var. serratus belongs within this variation (cf., Ignatov \& Afonina 1992; Newmaster 2007). The types of Aongstroemia curvicaulis Müll.Hal. (Müller 1898) and Cynodontium bicolor Paris (Paris 1900) also have strongly serrate leaf margins and clearly belong to $O$. virens as this species is understood here. The types of latter two names were checked to exclude that they belong to the next species.

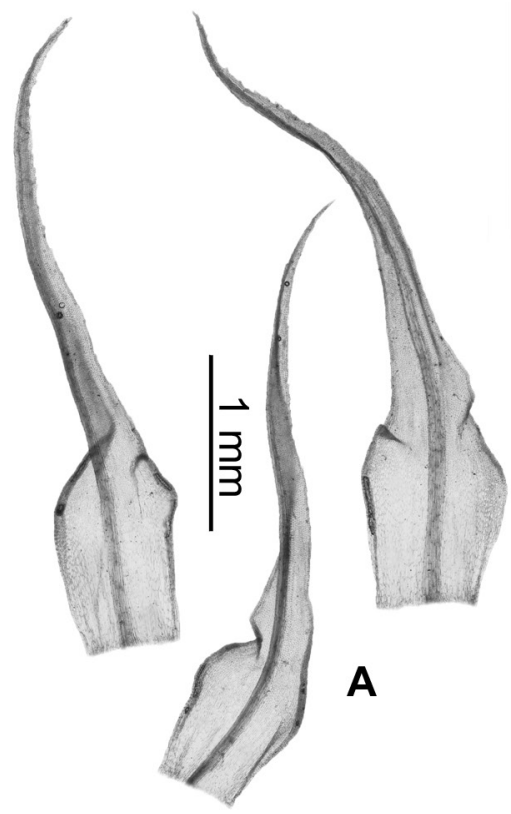

B
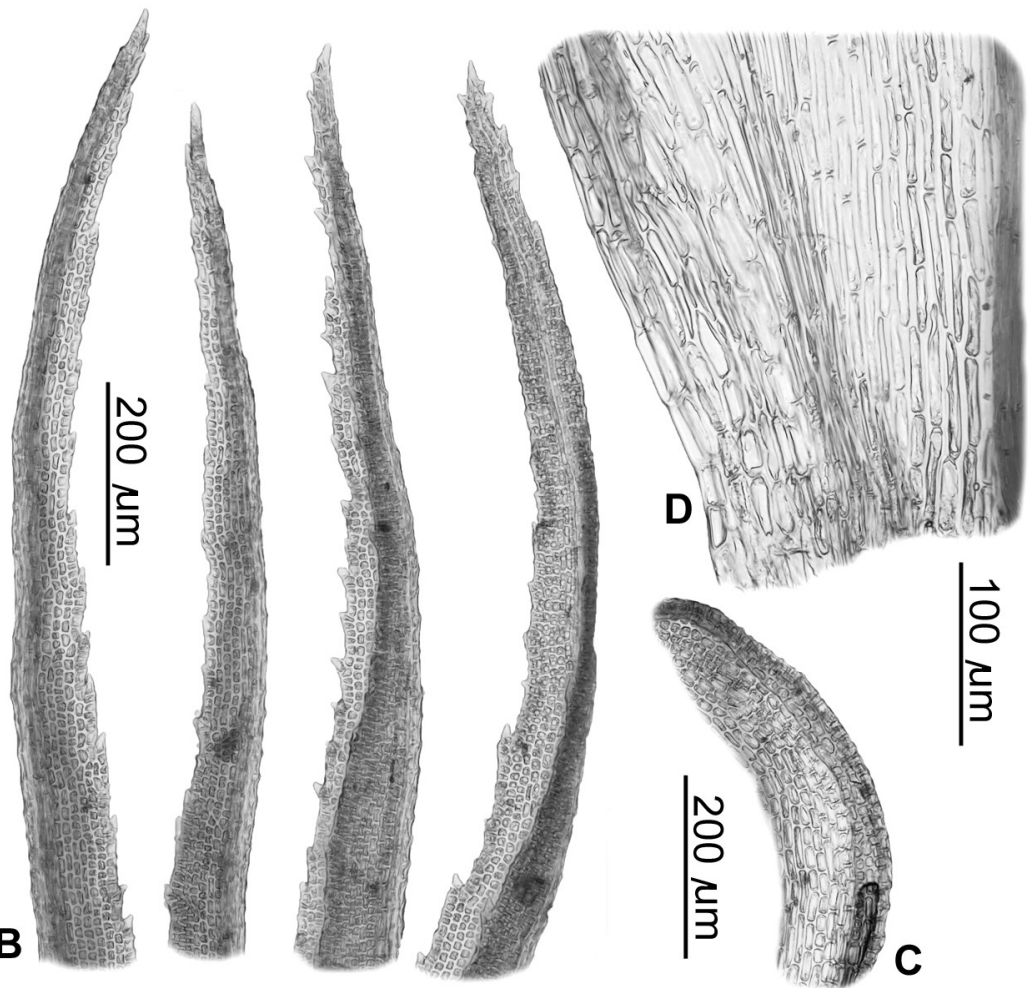

Fig. 9. Oncophorus virens (specimen P286; cf., Table 1). A. Stem leaves. B. Upper leaf acumen. C. Portion of leaf at widest point, showing the broadly recurved margin. D. Lower part of sheathing leaf portion, showing differentiated alar region (margin to the left). 


\section{Oncophorus integerrimus Hedenäs sp. nov.}

Fig. 10

Oncophorus virens var. elongatus Limpr., Die Laubmoose Deutschlands, Oesterreichs und der Schweiz 1: 309 (Limpricht 1886). - Cynodontium virens var. elongatum (Limpr.) Mönk., Die Laubmoose Europas: 195 (Mönkemeyer 1927). - Type: "An Quellen bei Innervillgraten in Tirol (Gander) und im Valée d'Eyne in den Pyrenäen 200 m (Renauld)” (syn-: BP, n.v.).

\section{Diagnosis}

Oncophorus integerrimus sp. nov. differs from $O$. virens (Hedw.) Brid. by its more loosely incurved leaves when dry, and in having entire or almost entire upper leaf margins.

\section{Etymology}

The epithet 'integerrimus' refers to the mostly entire leaf margin.

\section{Type material}

SWEDEN: Härjedalen, Tännäs, SW slope of Mt. Joltere (Lill-Mittåkläppen), 960 m a.s.l., periodically wet depression at margin of fen, 2 Sep. 2014, Lars Hedenäs s.n. (holo-: S, B207536!; iso-: BM!, NY!).

\section{Description}

Plants up to ten cm high, usually in loose tufts, green or yellow-green. Stem with large central strand, a cortex of (0-)1-3 layers of strongly incrassate cells, and an epidermis of one layer of thin-walled or slightly incrassate cells, sometimes partly differentiated as a hyalodermis; axillary hairs with 2-8-celled, hyaline upper portion, $8-12 \mu \mathrm{m}$ wide, basal $1-2$ cells rectangular, hyaline; rhizoids strongly branched, red-brown, smooth, in leaf axils. Leaves $2.7-5.0 \times 0.6-1.1 \mathrm{~mm}$, when moist from sheathing base erectpatent to spreading, straight or screwed, when dry loosely incurved and curled or twisted, from ovate or rounded-oblong base with longly and narrowly triangular acumen, apex longly acuminate; leaf margin at least partly distinctly recurved in lower leaf, below entire, in upper leaf mostly entire or indistinctly and obtusely denticulate, occasionally distinctly denticulate close to leaf apex, denticles single, margin varying from unistratose to bistratose; costa $75-146 \mu \mathrm{m}$ wide near base, with dorsal and ventral epidermis, one layer of large guide cells, 1-4 layers of ventral stereids and 2-4 layers of dorsal stereids; lamina cells in acumen incrassate, $6-38(-49) \times 5-15 \mu \mathrm{m}, 0.6-4.5(-5.8)$ times as long as wide, in mid-leaf incrassate, 6-42 $\times 4-12 \mu \mathrm{m}, 0.6-6.1(-7.2)$ times as long as wide, and in sheathing lamina slightly incrassate or incrassate and slightly porose, $16-91 \times 5-22 \mu \mathrm{m}, 1.4-12.4$ times as long as wide, transition between mid-leaf and basal cells gradual, due to relatively long mid-leaf cells and relatively short basal cells; alar cells differentiated, rectangular, slightly to strongly inflated and forming a diffusely delimited group of 3-5 cells wide and 3-5(-6) cells long, partly bistratose, decurrent. Perigonia lateral on stem, not stalked, antheridia protected by oblong perigonial leaves with "cut-off" or acute apex. Inner perichaetial leaves 4.29-6.02 mm long, lower 32-58\% oblong and broadly sheathing, above suddenly narrowed to long, narrow acumen. Seta tall, 18-27 mm; capsule cylindric, curved, with distinct struma, 1.3-1.8 $\times 0.5-$ $0.8 \mathrm{~mm}, 1.8-2.6$ times as long as broad, more or less orthogonal to homotropus; exothecial cells slightly incrassate or longitudinally incrassate, collenchymatous or not; stomata ovate-pored, surrounded by radially arranged cells, near base of capsule; peristome red, teeth cleft or perforated to middle or further down, with longitudinal rows of pits on outside; spores $18-28 \mu \mathrm{m}$, very finely rough.

\section{Remarks}

When well developed this is a large species, with on the average more longly and narrowly acuminate leaves than in $O$. virens. When dry, the leaves are loosely incurved or curved upwards, and the upper acumen is loosely but relatively strongly twisted. The leaf margin in the acumen is mostly entire, but 
sometimes slightly uneven or has a few and usually low and irregular obtuse teeth. Occasionally one or a few sharp teeth may occur, especially close to the leaf apex.

\section{Habitat and distribution in Scandinavia}

Oncophorus integerrimus sp. nov. is found most often in open wetlands, but occurs also on soil and wet rocks, often on shores (Fig. 4). The distribution of O. integerrimus sp. nov. is similar to that of $O$. virens, but geographically more restricted (Fig. 3D). Of the four Scandinavian Oncophorus species it is the only one that has not been found in southern Sweden, although there are few finds from southern Norway.

\section{Nomenclatural note}

The synonymy of Oncophorus virens var. elongatus Limpr. is based on protologue information (Limpricht 1886) and on material collected by Gander at the type locality two years after the description of the taxon (S-B232585). The name of the variety cannot be used at the species level, since it is blocked by Oncophorus elongatus (I.Hagen) Hedenäs.

\section{Discussion}

Although the monophyly of Oncophorus was not an issue in the present study, the positions of its species in relation to Cynodontium strumiferum and Rhabdoweisia fugax do not suggest otherwise. Neither in the ITS- nor chloroplast-based analyses, $O$. crispifolius, $O$. dendrophilus, and $O$. rauei were found in positions that suggested that they are especially closely related to any of the Scandinavian species. The molecular evidence presented here supports the recognition of the recently described $O$. dendrophilus (Hedderson \& Blockeel 2006).
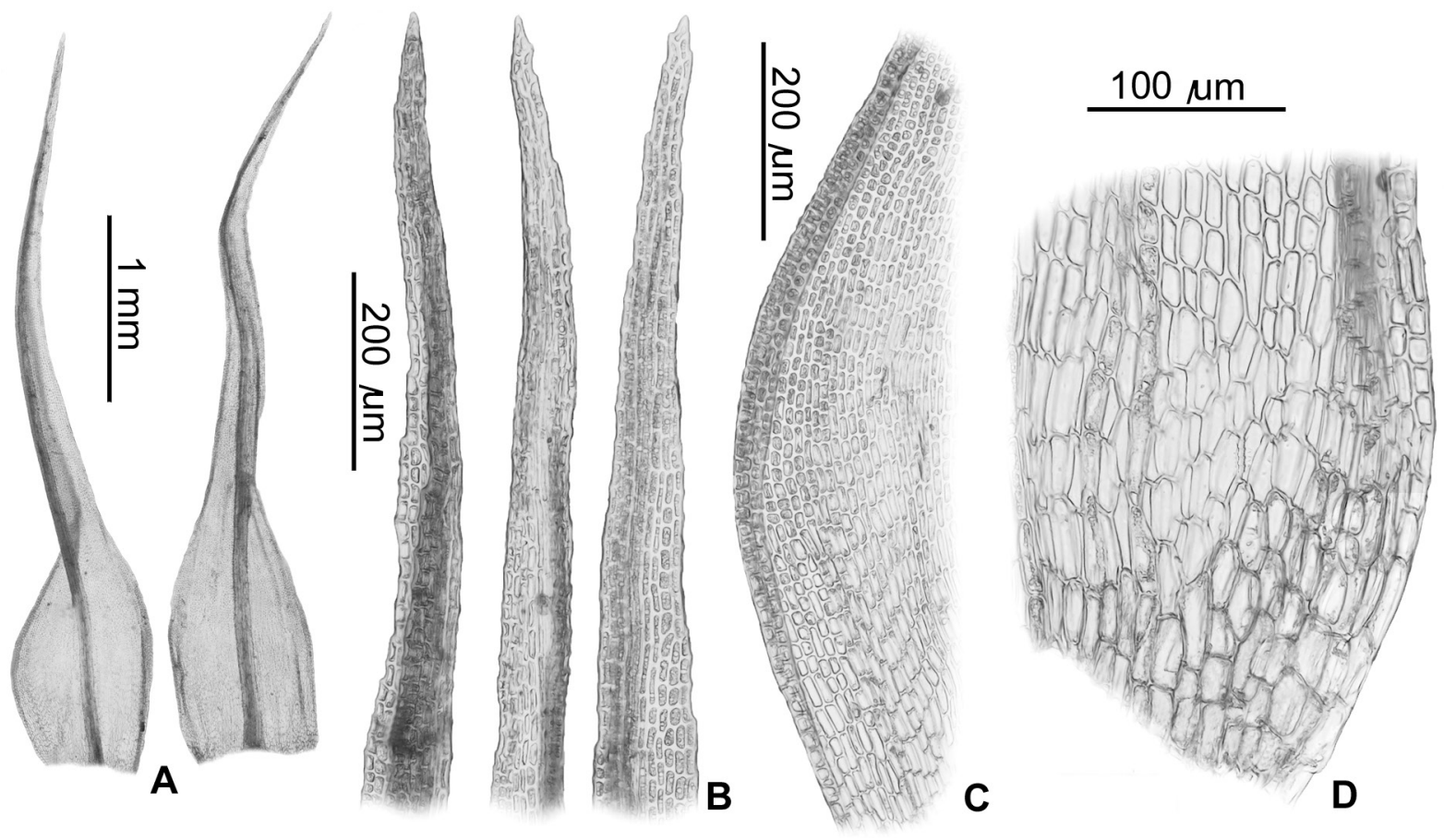

Fig. 10. Oncophorus integerrimus Hedenäs sp. nov (holotype). A. Stem leaves. B. Upper leaf acumen. C. Portion of leaf at widest point, showing the broadly recurved margin. D. Lower part of sheathing leaf portion, showing differentiated alar region (margin to the right). 
The molecular information available for Scandinavian Oncophorus suggests that species additional to the ones so-far accepted exist in the area. Four molecularly supported entities can also be distinguished based on their morphology, by a few qualitative characters, statistically significant differences in leaf cell measurements or on PCA scores based on these and leaf size. Four is therefore the minimum number of species to be recognized in the area. However, additional evolutionary lineages and in some cases most likely also biologically distinct cryptic species occur among the Scandinavian Oncophorus, considering the number of mutational differences between lineages as well as the lack of intermediates between these lineages. Cryptic species are here understood as lineages that are molecularly as distinct as those of the morphologically recognized species but which lack (known) morphological distinguishing features. For semi-cryptic species, weak quantitative morphological differentiation towards other molecularly identified entities is presently suggested by the data.

The two species Oncophorus elongatus and $O$. wahlenbergii are easily distinguished from $O$. virens and $O$. integerrimus sp. nov. by their plane rather than partially recurved leaf margins. Oncophorus elongatus differs from $O$. wahlenbergii in the shape of the marginal cells of the sheathing leaf portion, the denticulation or dentation of the upper leaf margins and costa, and overall leaf size, and except for O. wahlenbergii B in the quantitative leaf characters included in the PCA (Fig. 2A). Within O. elongatus one specimen shifted between $O$. elongatus A and B depending on whether ITS or chloroplast data were analysed. Such incongruence could be a result of several processes, such as incomplete lineage sorting or hybridization, but to determine the cause additional evidence is required (cf., Wendel \& Doyle 1998; Harris 2008). On the other hand, there appears to be a phylogeographic signal distinguishing O. elongatus $\mathrm{B}$ as a western, oceanic or sub-oceanic entity that was mostly collected in fens and had usually got the long leaf portions above the sheathing base widely spreading, in contrast with the predominantly more eastern $O$. elongatus A that was mainly collected on dead wood or rocks and mostly presented less or not spreading leaves. Combined with the incomplete congruence between the two molecular data sets, this could be interpreted as two lineages that are still in the process of diverging. The distinct habit of O. elongatus B made Hedenäs (2005) believe that only this kind of plants belongs to O. elongatus, which is now shown to be incorrect. Oncophorus elongatus $\mathrm{C}$ is clearly distinct from O. elongatus A and B by 5-6 mutational changes according to both ITS and chloroplast data. Because only two of the sampled specimens belong to this lineage and no morphological feature was found that supports it, O. elongatus $\mathrm{C}$ is best treated as a potential cryptic species that requires further study.

Within $O$. wahlenbergii several well-supported molecular lineages that are differentiated by numerous mutations and have a high jacknife support exist. It seems likely that the three distinct lineages that are present in $O$. wahlenbergii represent cryptic species, or in the case of $O$. wahlenbergii $\mathrm{B}$, which in some quantitative morphological traits overlaps more with $O$. elongatus than with $O$. wahlenbergii (Fig. 2A, Table 2), semi-cryptic species. The sampling of specimens from two of these three lineages occurred by pure chance, since neither $O$. wahlenbergii B nor $\mathrm{C}$ was clearly distinguishable by morphology alone. It is possible that a fuller sampling of $O$. wahlenbergii $\mathrm{B}$, that allows comparing additional specimens with $O$. wahlenbergii $\mathrm{A}$ and $\mathrm{C}$, would make it possible to refer at least a significant proportion of $O$. wahlenbergii $\mathrm{B}$ specimens to this lineage by morphology. According to ITS data, $O$. wahlenbergii $\mathrm{C}$ appears on another side of a major split than $O$. wahlenbergii A and B, O. crispifolius, $O$. dendrophilus, and $O$. rauei, which suggests that this lineage is more isolated than $O$. wahlenbergii $\mathrm{B}$ from $O$. wahlenbergii A, despite that $O$. wahlenbergii B is the one that may deviate morphologically from the latter.

Oncophorus integerrimus sp. nov. includes no jacknife-supported intraspecific variation. The leaf margins of $O$. integerrimus are entire, or occasionally denticulate near leaf apex, whereas $O$. virens has predominantly dentate or coarsely denticulate upper leaf margins; the species also differ in the quantitative leaf characters that were included in the PCA (Fig. 2B). Oncophorus virens displays intraspecific variation that is mainly incongruent between ITS and chloroplast data (cf., O. elongatus 
above), except that $O$. virens $\mathrm{B}$ is distinct from $O$. virens $\mathrm{A}$ in both data sets. All seven specimens of $O$. virens $\mathrm{B}$ came from higher elevations than any of the 15 O. virens A specimens (Fig. 5B). This is highly unlikely as a chance result and therefore suggests that $O$. virens $\mathrm{B}$ is restricted to the cold climate of higher mountains. Since the temperature in the mountains is expected to increase with several degrees until the year 2100 (Berglöv et al. 2015a, 2015b; Nylén et al. 2015), it is urgent to examine the distribution of $O$. virens B and similarly distributed species and intraspecific entities in more detail. Organisms restricted to cold environments, such as $O$. virens B and the northern haplotypes of Scorpidium cossonii (Schimp.) Hedenäs (Hedenäs 1989) (Hedenäs 2009), will likely decline when the areas of suitably cold habitats shrink.

All four species that can be clearly distinguished by morphology have relatively northern distributions and are especially common in the mountain range and the lowlands of the far north (Fig. 3). The mapped distributions clearly underestimate the frequency of the species in Norway, since the mapped occurrences are based on S material only and the distribution of members of the genus Oncophorus is much wider according to 'Artskart' (https://artskart.artsdatabanken.no/; accessed 9 Feb. 2016).

All four species occur with different frequencies in several humid to wet habitats (Fig. 4). Oncophorus elongatus obviously prefers organic substrates, such as decomposing wood and peaty soil in mires, whereas $O$. virens is clearly a species of brook and lake shores, and wet rocks, and is the only species that is often found in late snow-beds. The two remaining species are most frequently found in mire habitats, but are relatively abundant also on brook and lake shores, and wet rocks. Oncophorus elongatus and $O$. wahlenbergii occur in relatively base-poor environments, whereas $O$. virens and $O$. integerrimus sp. nov. are mostly found in base-rich to calcareous habitats. Whether entities within species that display clear intraspecific molecular variation also differ from each other in habitat preferences should be explored when molecular information exists for additional specimens.

From a biodiversity and conservation point of view the cryptic diversity in Oncophorus deserves serious attention (Hedenäs 2016). A fuller sampling of O. virens, O. elongatus, and $O$. wahlenbergii is required to understand their cryptic and semi-cryptic diversities, as well as intrinsic geographic and habitat components. Additionally, this would possibly allow the discovery of morphologically stable characters to distinguish at least $O$. wahlenbergii $\mathrm{B}$. However, at the present state of knowledge, and considering the wish by most biologists to be able to distinguish species by morphology, four 'species' of Oncophorus are here recognized for Scandinavia.

\section{Acknowledgements}

I thank Bodil Cronholm for her excellent laboratory work, L. Ellis at BM for a loan of type material, and T.L.Blockeel for a gift and a loan of $O$. dendrophilus material. Two reviewers provided comments that significantly improved the text. Financial support for the molecular work was received from the Swedish Taxonomy Initiative (dha 2014-79 4.3).

\section{References}

Arnell H.W. \& Jensen C. 1896. Ein bryologischer Ausflug nach Tåsjö. Mit einer Karte und einer Tafel. Bihang till Kongliga Svenska Vetenskaps-Akademiens Handlingar 21 Afd. 3 (10): 1-64.

Berglöv G., Asp M., Berggreen-Clausen S., Björck E., Axén Mårtensson J., Nylén L., Ohlsson A., Persson H. \& Sjökvist E. 2015a. Framtidsklimat i Norrbottens län - enligt RCP-scenarier. SMHI Klimatologi 32: $1-75$. 
Berglöv G., Asp M., Berggreen-Clausen S., Björck E., Axén Mårtensson J., Nylén L., Ohlsson A., Persson H. \& Sjökvist E. 2015b. Framtidsklimat i Västerbottens län - enligt RCP-scenarier. SMHI Klimatologi 33: 1-75.

Bickford D., Lohman D.J., Sodhi N.S., Ng P.K.L., Meier R., Winker K., Ingram K.K. \& Das I. 2006. Cryptic species as a window on diversity and conservation. Trends in Ecology \& Evolution 22: 148-155. https://doi.org/10.1016/j.tree.2006.11.004

Braithwaite R. 1883. The British Moss-Flora. Vol. 1. Published by the author, London.

Bridel S.E. von 1826. Bryologia universa seu systematica ad novam methodum dispositio, historia et descriptio omnium muscorum frondosorum huscusque cognitorum cum synonymia ex auctoribus probatissimis. Vol. 1. J.A. Barth, Leipzig.

Brotherus V.F. 1901. II. Specieller Teil. Mit zahlreichen Einzelbildern in vielen Figuren. Die Natürlichen Pflanzenfamilien I (3): 277-1172.

Brotherus V.F. \& Saelan T. 1890. Musci Lapponiae kolaënsis. Acta Societatis pro Fauna et Flora Fennica 6 (4): 3-100.

Bruch P. \& Schimper W.P. 1846. Bryologia Europaea seu genera muscorum Europaeorum monographice illustrata. Vol. 1. Fasc. 33-36. E. Schweizerbart, Stuttgart.

Bruch P. \& Schimper W.P. 1847. Bryologia Europaea seu genera muscorum Europaeorum monographice illustrata. Vol. 1. Fasc. 37-40. E. Schweizerbart, Stuttgart.

Bruch P., Schimper W.P. \& Gümbel T. 1836-1851. Bryologia Europaea seu genera muscorum Europaeorum monographice illustrata. Vol. I. E. Schweizerbart, Stuttgart.

Buchbender V., Hespanhol H., Krug M., Sérgio C., Séneca A., Maul K., Hedenäs L. \& Quandt D. 2014. Phylogenetic reconstructions of the Hedwigiaceae reveal cryptic speciation and hybridisation in Hedwigia. Bryophyte Diversity and Evolution 1: 1-21. https://doi.org/10.11646/bde.36.1.1

Carter B.E. 2012a. Scleropodium occidentale (Brachytheciaceae), a new moss species from western North America. The Bryologist 115: 222-230. https://doi.org/10.1639/0007-2745-115.2.222

Carter B.E. 2012b. Species delimitation and cryptic diversity in the moss genus Scleropodium (Brachytheciaceae). Molecular Phylogenetics and Evolution 63: 891-903. https://doi.org/10.1016/j. ympev.2012.03.002

Clement M., Posada D. \& Crandall K.A. 2000. TCS: a computer program to estimate gene genealogies. Molecular Ecology 9: 1657-1659. https://doi.org/10.1046/j.1365-294x.2000.01020.x

Crawford D.J. \& Stuessy T.F. 2016. Cryptic variation, molecular data, and the challenge of conserving plant diversity in oceanic archipelagos: the critical role of plant systematics. Korean Journal of Plant Taxonomy 46: 129-148. https://doi.org/10.11110/kjpt.2016.46.2.129

Dixon H.N. 1926. Mosses collected in Gilgit etc., by J. Garrett and W. Lillie. Records of the Botanical Survey of India 9 (5): 303-313.

Doweld A.B. 2001. Prosyllabus tracheophytorum. Tentamen systematis plantarum vascularium (Tracheophyta). Geos, Moscow.

Draper I., Hedenäs L., Stech M., Patiño J., Werner O., González-Mancebo J.M., Sim-Sim M., Lopes T. \& Ros R.M. 2015. How many species of Isothecium (Lembophyllaceae, Bryophyta) are there in Macaronesia? A survey using integrative taxonomy. Botanical Journal of the Linnean Society 177: 418438. https://doi.org/10.1111/boj.12250 
Farris J.S., Källersjö M., Kluge A.G. \& Bult C. 1995. Testing significance of incongruence. Cladistics 10: 315-319. https://doi.org/10.1111/j.1096-0031.1994.tb00181.x

Feliner G.N. \& Rosselló J.A. 2007. Better the devil you know? Guidelines for insightful utilization of nrDNA ITS in species-level evolutionary studies in plants. Molecular Phylogenetics and Evolution 44: 911-919. https://doi.org/10.1016/j.ympev.2007.01.013

Fleischer M. 1920. Natürliches System der Laubmoose. Hedwigia 61: 390-400.

Frahm J.-P., Buchbender V., Lachmann S., Reifenrath K. \& Werner F. 1998. Revision der Gattung Oncophorus (Musci, Dicranaceae). Tropical Bryology 14: 119-131.

Frey W. \& Stech M. 2009. Division of Bryophyta Schimp. (Musci, Mosses). In: Frey W. (ed.) Syllabus of Plant Families. Adolf Engler's Syllabus der Pflanzenfamilien. 13 ${ }^{\text {th }}$ edition. Part 3. Bryophytes and seedless vascular plants: 116-257. Gebrüder Borntraeger, Berlin.

Goffinet B., Buck W.R. \& Shaw A.J. 2008. Morphology, anatomy, and classification of the Bryophyta. In: Goffinet B. \& Shaw A.J. (eds) Bryophyte biology. $2^{\text {nd }}$ edition: 55-138. Cambridge University Press, Cambridge.

Goloboff P., Farris J. \& Nixon K. 2003. Tree analysis using new technology. Available from http://www. lillo.org.ar/phylogeny/ [accessed 24 Apr. 2017].

Grout A.J. 1937. Moss Flora of North America (North of Mexico). Vol. 1. Published by the Author, Newfane, Vermont.

Hagen I. 1899. Musci norvegiae borealis. Tromsö Museums Aarshefter 21-22 (1): 1-112.

Hallingbäck T., Lönnell N., Weibull H., Hedenäs L. \& Knorring P. von 2006. Nationalnyckeln till Sveriges flora och fauna. Bladmossor: Sköldmossor-blåmossor. Bryophyta: Buxbaumia-Leucobryum. ArtDatabanken, SLU, Uppsala.

Harris E.S.J. 2008. Paraphyly and multiple causes of phylogenetic incongruence in the moss genus Plagiomnium (Mniaceae). Taxon 57: 417-433.

Hartman C.J. 1832. Handbok i Skandinaviens flora, innefattande Sveriges och Norriges vexter, till och med mossorna. Med en öfversigt af vextläran och botanikens studium i allmänhet. Andra upplagan, omarbetad och förökad. $2^{\text {nd }}$ edition. Z. Hæggströms, Stockholm.

Hartman C.J. 1871. Handbok i Skandinaviens Flora, innefattande sveriges och norges växter till och med mossorna. Utgifen mer Rättelser och tillägg af Carl Hartman. Sednare delen: Mossor. [Part 2]. 10 ${ }^{\text {th }}$ edition. Z. Hæggströms, Stockholm.

Hawksworth D.L. 2001. The magnitude of fungal diversity: the 1.5 million species estimate revisited. Mycological Research 105: 1422-1432. https://doi.org/10.1017/S0953756201004725

Hedderson T.A. \& Blockeel T.L. 2006. Oncophorus dendrophilus, a new moss species from Cyprus and Crete. Journal of Bryology 28: 357-359. https://doi.org/10.1179/174328206X152324

Hedenäs L. 1989. The genera Scorpidium and Hamatocaulis, gen. nov., in Northern Europe. Lindbergia 15 (1): 8-36.

Hedenäs L. 2005. Oncophorus wahlenbergii var. elongatus I. Hagen, an overlooked taxon in northern Europe. Lindbergia 30: 32-38.

Hedenäs L. 2009. Relationships among arctic and non-arctic haplotypes of the moss species Scorpidium cossonii and Scorpidium scorpioides (Calliergonaceae). Plant Systematics and Evolution 277: 217-231. https://doi.org/10.1007/s00606-008-0131-y 
Hedenäs L. 2016. Intraspecific diversity matters in bryophyte conservation - internal transcribed spacer and rpl16 G2 intron variation in European mosses. Journal of Bryology: 173-182. https://doi.org/10.10 $\underline{80 / 03736687.2016 .1145522}$

Hedenäs L., Désamoré A., Laenen B., Papp B., Quandt D., González-Mancebo J.M., Patiño J., Vanderpoorten A. \& Stech M. 2014. Three species for the price of one within the moss Homalothecium sericeum s.1. Taxon 63: 249-257. https://doi.org/10.12705/632.16

Hedwig J. 1801. Species muscorum frondosorum: descriptae et tabulis aeneis lxxvii coloratis illustratae. J.A. Barthii, Leipzig; A. Koenig, Paris.

Heinrichs J., Hentschel J., Bombosch A., Fiebig A., Reise J., Edelmann M., Kreier H.-P., Schäfer-Verwimp A., Caspari S., Schmidt A.R., Zhu R.-L., Konrat M. von, Shaw B. \& Shaw A.J. 2010. One species or at least eight? Delimitation and distribution of Frullania tamarisci (L.) Dumort. s. 1. (Jungermanniopsida, Porellales) inferred from nuclear and chloroplast DNA markers. Molecular Phylogenetics and Evolution 56: 1105-1114. https://doi.org/10.1016/j.ympev.2010.05.004

Herzog T. 1910. Kritische u. neue Arten der europäischen Laubmoosflora. Allgemeine Botanische Zeitschrift für Systematik, Floristik, Pflanzengeographie 16: 81-85.

Howis S., Barker N.P. \& Mucina L. 2009. Globally grown, but poorly known: species limits and biogeography of Gazania Gaertn. (Asteraceae) inferred from chloroplast and nuclear DNA sequence data. Taxon 58: 871-882.

Hübener J.W.P. 1833. Muscologia Germanica, oder beschreibung der Deutschen Laubmoose. F. Hofmeister, Leipzig.

Huson D.H. \& Bryant D. 2006. Application of phylogenetic networks in evolutionary studies. Molecular Biology and Evolution 23: 254-267. https://doi.org/10.1093/molbev/msj030

Ignatov M.S. \& Afonina O.M. 1992. Check-list of mosses of the former USSR. Arctoa 1: 1-85.

Košnar J., Herbstová M., Kolář F., Koutecký P. \& Kučera J. 2012. A case of intragenomic ITS variation in bryophytes: Assessment of gene flow and role of plyploidy in the origin of European taxa of the Tortula muralis (Musci: Pottiaceae) complex. Taxon 61: 709-720.

Limpricht K.G. 1886. Die Laubmoose Deutschlands, Oesterreichs und der Schweiz. I. Abtheilung. Lieferung 5. Verlag von Eduard Kummer, Leipzig.

Lindberg S.O. 1864. De Tortulis et ceteris Trichostomeis europæis. Öfversigt af Kongelige VetenskapsAkademiens Förhandlingar 21: 213-254.

Lindberg S.O. 1872. Contributio ad Floram Cryptogamam Asice Boreali-Orientalis. Societatis Litterariæ Fennicæ, Helsingfors.

Mönkemeyer W. 1927. Die Laubmoose Europas. IV. Band, Ergänzungsband. Andreaeales-Bryales. Akademische Verlagsgesellschaft m.b.H, Leipzig.

Müller C. 1851. Synopsis muscorum frondosorum omnium hucusque cognitorum. Vol. 2. A. Foerstner, Berlin.

Müller C. 1898. Bryologia provinciae Schen-Si sinensis ex collectione Giraldiana III. Nuovo Giornale Botanico Italiano, n.s. 5 (2): 158-209.

Müller K. 2005. SeqState. Applied Bioinformatics 4: 65-69. https://doi.org/10.2165/00822942200504010-00008

Nadot S., Bajon R. \& Lejeune B. 1994. The chloroplast gene rps 4 as a tool for the study of Poaceae phylogeny. Plant Systematics and Evolution 191: 27-38. https://doi.org/10.1007/BF00985340 
Newmaster S.G. 2007. Oncophorus (Bridel) Bridel, Muscol. Recent., suppl. 4:53. 1819. In: Committee FoNAE (ed.) Flora of North America North of Mexico. Vol. 27: 423-424. Oxford University Press, New York, Oxford.

Nyholm E. 1987. Illustrated Flora of Nordic Mosses. Fasc. 1. Fissidentaceae-Seligeriaceae. Nordic Bryological Society, Copenhagen, Lund.

Nylén L., Asp M., Berggreen-Clausen S., Berglöv G., Björck E., Axén Mårtensson J., Ohlsson A., Persson H. \& Sjökvist E. 2015. Framtidsklimat i Jämtlands län - enligt RCP-scenarier. SMHI Klimatologi 34: $1-75$.

Nylinder S., Cronholm B., Lange P.J. de, Walsh N. \& Anderberg A.A. 2013. Species tree phylogeny and character evolution in the genus Centipeda (Asteraceae): evidence from DNA sequences from coding and non-coding loci from the plastid and nuclear genomes. Molecular Phylogenetics and Evolution 68: 239-250. https://doi.org/10.1016/j.ympev.2013.03.020

Pacak A. \& Szweykowska-Kulińska Z. 2000. Molecular data concerning alloploid character and the origin of chloroplast and mitochondrial genomes in the liverwort species Pellia borealis. Journal of Plant Biotechnology 2: 101-108.

Paris E.G. 1900. Index Bryologicus sive enumeratio muscorum hucusque cognitorum. Supplementum Primum. Georg \& Cie, Geneva, Basel.

Pax F.A. 1900. Prantl's Lehrbuch der Botanik. 11 ${ }^{\text {th }}$ edition. Wilhelm Engelmann, Lepizig.

Rydin C., Pedersen K.R. \& Friis E.M. 2004. On the evolutionary history of Ephedra: Cretaceous fossils and extant molecules. Proceedings of the National Academy of Sciences of the United States of America 101: 16571-16576. https://doi.org/10.1073/pnas.0407588101

Schimper W.P. 1856. Corollarium Bryologiae Europaeae, conspectum diagnosticum familiarum, generum et specierum, adnotationes novas atque emendationes complectens. E. Schweizerbart, Stuttgart.

Schultz C.F. 1828. Observationes Bryologicae. Particula prima. In: Hornschuch C.F. (ed.) Sylloge plantarum novarum itemque minus cognitarum. Vol. 2: 119-154. C.E. Brenck, Regensburg.

Shaw A.J., McDaniel S.F., Werner O. \& Ros R.M. 2002. New frontiers in bryology and lichenology. Phylogeography and phylodemography. The Bryologist 105: 373-383.

Simmons M.P. \& Ochoterena H. 2000. Gaps as characters in sequence-based phylogenetic analyses. Systematic Biology 49: 369-381. https://doi.org/10.1093/sysbio/49.2.369

Souza-Chies T.T., Bittar G., Nadot S., Carter L., Besin E. \& Lejeune B. 1997. Phylogenetic analysis of Iridaceae with parsimony and distance methods using the plastid gene rps4. Plant Systematics and Evolution 204: 109-123. https://doi.org/10.1007/BF00982535

StatSoft I. 2013. STATISTICA (data analysis software system), version 12. Available from http://www. statsoft.com [accessed 1 May 2013].

Stech M. \& Frey W. 2008. A morpho-molecular classification of the mosses. Nova Hedwigia 86: 1-21. https://doi.org/10.1127/0029-5035/2008/0086-0001

Stech M., McDaniel S.F., Hernández-Maqueda R., Ros R.M., Werner O., Muñoz J. \& Quandt D. 2012. Phylogeny of haplolepideous mosses - challenges and perspectives. Journal of Bryology 34: 173-186. https://doi.org/10.1179/1743282012Y.0000000014

Thiers B. Continuously updated. Index Herbariorum: a global directory of public herbaria and associated staff. New York Botanical Garden's Virtual Herbarium. Available from http://sweetgum. nybg.org/science/ih/ [accessed 21 Mar. 2017]. 
Wendel J.F. \& Doyle J.J. 1998. Phylogenetic incongruence: window into genome history and molecular evolution. In: Soltis D.E., Soltis P.S. \& Doyle J.J. (eds) Molecular systematics of plants II. DNA sequencing: 265-296. Chapman and Hall, New York. https://doi.org/10.1007/978-1-4615-5419-6 10

Manuscript received: 2 June 2016

Manuscript accepted: 23 August 2016

Published on: 2 May 2017

Topic editor: Koen Martens

Desk editor: Natacha Beau

Printed versions of all papers are also deposited in the libraries of the institutes that are members of the EJT consortium: Muséum national d'Histoire naturelle, Paris, France; Botanic Garden Meise, Belgium; Royal Museum for Central Africa, Tervuren, Belgium; Natural History Museum, London, United Kingdom; Royal Belgian Institute of Natural Sciences, Brussels, Belgium; Natural History Museum of Denmark, Copenhagen, Denmark; Naturalis Biodiversity Center, Leiden, the Netherlands; Museo Nacional de Ciencias Naturales-CSIC, Madrid, Spain; Real Jardín Botánico de Madrid CSIC, Spain. 